Article

\title{
Back to the Future: The Digital Millennium Copyright Act and the Trans-Pacific Partnership
}

\author{
Matthew Rimmer
}

Faculty of Law, Queensland University of Technology, 2 George Street GPO Box 2434, Brisbane, Queensland 4001, Australia; matthew.rimmer@qut.edu.au; Tel.: +61-(07)-3138-1599

Received: 1 May 2017; Accepted: 8 July 2017; Published: 12 August 2017

\begin{abstract}
The Trans-Pacific Partnership (TPP) is a trade agreement, which seeks to regulate copyright law, intermediary liability, and technological protection measures. The United States Government under President Barack Obama sought to export key features of the Digital Millennium Copyright Act 1998 (US) (DMCA). Drawing upon the work of Joseph Stiglitz, this paper expresses concerns that the TPP would entrench DMCA measures into the laws of a dozen Pacific Rim countries. This study examines four key jurisdictions-the United States, Canada, Australia, and New Zealand-participating in the TPP. This paper has three main parts. Part 2 focuses upon the takedown-and-notice scheme, safe harbours, and intermediary liability under the TPP. Elements of the safe harbours regime in the DMCA have been embedded into the international agreement. Part 3 examines technological protection measures-especially in light of a constitutional challenge to the $D M C A$. Part 4 looks briefly at electronic rights management. This paper concludes that the model of the DMCA is unsuitable for a template for copyright protection in the Pacific Rim in international trade agreements. It contends that our future copyright laws need to be responsive to new technological developments in the digital age—-such as Big Data, cloud computing, search engines, and social media. There is also a need to resolve the complex interactions between intellectual property, electronic commerce, and investor-state dispute settlement in trade agreements.
\end{abstract}

Keywords: trans-pacific partnership; copyright law; intermediary liability; safe harbours; technological protection measures; electronic rights management information; intellectual property; investor-state dispute settlement; electronic commerce; international trade law

\section{Introduction}

The Trans-Pacific Partnership (TPP) has sought to provide for stronger copyright enforcement mechanisms across the Pacific Rim (Kelsey 2010; Voon 2013; Lim et al. 2012; Sinclair and Trew 2016; Australia Government Department of Foreign Affairs and Trade 2015a, 2016a; The United States Trade Representative 2016).

On the 28 October 1998, President Bill Clinton signed the Digital Millennium Copyright Act 1998 (US) in order to update United States copyright law for the digital age (DMCA). In her classic 2001 book, Digital Copyright, Professor Jessica Litman recalls the machinations behind the construction of the lengthy, prolix DMCA (Litman 2001). She reflected that the process resulted in a complicated set of compromises:

Copyright legislation written by multiparty negotiation is long, detailed, counterintuitive, kind to the status quo, and hostile to potential new competitors. It is also overwhelmingly likely to appropriate value for the benefit of major stakeholders at the expense of the public at large. There is no overarching of the public interest animating the DMCA. None. Instead, what we have is what a variety of different private parties were able to extract from each other in the course of an incredibly complicated four-year multiparty negotiation. 
Unsurprisingly, they paid for that with a lot of rent-seeking at the expense of new upstart industries and the public at large (Litman 2001, pp. 144-45).

Summing up her concerns about his legislative matrix, Litman observed: "The DMCA is long, internally inconsistent, difficult even for copyright experts to parse and harder still to explain" (Litman 2001, p. 145). Such comments certainly seem prophetic, given how the DMCA has fared in copyright litigation and policy debates. While cloaked in the language of technology neutrality, the $D M C A$ in retrospect seems a technologically specific set of legislative instructions (Craig 2017).

Despite its politically complicated origins, the United States Trade Representative has repeatedly sought to export the model of the DMCA through a range of bilateral, plurilateral, and regional agreements. There has been a concern that copyright holders have captured international copyright law through the United States trade regime (Kaminski 2014).

The United States Trade Representative first sought to disseminate such DMCA measures through a range of bilateral trade agreements (Drahos 2001; Okediji 2003-2004; Sell 2011). Under the leadership of President George W. Bush, the United States Trade Representative forged a number of bilateral agreements, featuring detailed intellectual property chapters. The Australia-United States Free Trade Agreement 2004 was representative of such initiatives (Rimmer 2006, 2007). Such agreements contained TRIPS + measures, which were above and beyond the obligations found under the TRIPS Agreement 1994. ${ }^{1}$ The United States Trade Representative demanded that its trading partners ratify and implement the WIPO Internet Treaties $1996 .^{2}$ Moreover, the United States Trade Representative mandated that its trading partners adopt certain features of the DMCA specifically, such as the safe harbours regime, technological protection measures, and electronic rights management.

Building upon such bilateral agreements, the United States Trade Representative under President Barack Obama attempted to further globalise such copyright rules and norms with the Anti-Counterfeiting Trade Agreement (ACTA). ${ }^{3}$ ACTA sought to introduce detailed provisions on copyright law and piracy, trademark law and counterfeiting, and customs and border measures. However, the proposed regime met with concerted resistance from legislators, stakeholders, and civil society (Horten 2013; Haggart 2014; Rimmer 2014; Roffe and Seuber 2014). In the end, ACTA collapsed in light of concerted criticism from the European Parliament in particular.

With his customary soaring rhetoric, President Barack Obama promoted the TPP as a 21st century agreement, which would promote digital trade, electronic commerce and internet freedom. Obama eloquently promised that the TPP "promotes a free and open Internet" (Obama 2015). In spite of such high-minded rhetoric, the substance of the agreement raised questions about whether it would in fact stymie a free and open Internet. Despite the collapse of $A C T A$, a number of its key measures were resurrected in the TPP. The TPP contains detailed, prescriptive text on intermediary liability and copyright law. It is questionable whether this anachronistic model is appropriate and well-adapted for other countries in the Pacific Rim in the digital age. The TPP seeks to lock in United States-style provisions in respect of technological protection measures. This is unwise given concerns about the efficacy of the regime; the collateral impact of uber-copyright on a range of other public policy interests; and the current constitutional challenge to the technological protection measures regime in the DMCA. The TPP also seeks to embed a United States-style regime in relation to electronic rights management information. Again, such an approach is questionable - given that such measures have proven to have little utility.

The TPP provides for an arsenal of copyright enforcement measures relating to civil remedies, criminal offences, border measures, government computer software, satellite piracy, and law enforcement co-operation. There has been significant debate about whether such measures are balanced

\footnotetext{
TRIPS Agreement 19941869 UNTS 299; 33 ILM 1197 (1994).

2 WIPO Copyright Treaty 1996 S. Treaty Doc. No. 105-17 (1997); 36 ILM 65(1997); and WIPO Performances and Phonograms Treaty 1996 S. Treaty Doc. No. 105-17, 36 ILM 76 (1997).

3 Anti-Counterfeiting Trade Agreement 2011, [2011] ATNIF 22, not yet in force.
} 
and proportionate. Moreover, there have been larger concerns raised about the impact of the TPP upon due process, privacy, civil liberties, freedom of speech, and human rights (Fulton 2012). The turn of the century $D M C A$ measures seem unfit for purpose for a supposedly 21st century trade agreement like the TPP. The nostalgic DMCA regime is ill-adapted for an age of search engines, social media, Big Data, cloud computing, 3D Printing, and the Internet of Things.

Even while the United States Trade Representative has sought to lock in the DMCA through the $T P P$, the United States Copyright Office, the United States Congress, and a wide spectrum of copyright stakeholders have discussed the development of the "Next Great Copyright Act" (Pallante 2013). There have been significant hearings on key measures such as the takedown and notice scheme, safe harbours for online intermediaries, technological protection measures, and electronic rights management information. The United States Copyright Office is currently undertaking a public study to evaluate the impact and effectiveness of the safe harbour provisions (United States Copyright Office 2017a). This has involved a public roundtable, and a wide array of public comments. Likewise, the United States Copyright Office has also been undertaking a public study of the operation of the technological protection measures regime in the DMCA (United States Copyright Office 2017b). There has been a range of public comments and roundtables on the topic. The final report was published in June 2017 (United States Copyright Office 2017c). There would seem to be significant tensions between the push to entrench DMCA measures in the TPP, and the need to evaluate and reform the DMCA measures within the United States system.

This paper will engage in an evaluation of the DMCA features of the TPP. In terms of its methodology, this paper relies upon a mixture of approaches to make sense of the TPP. As a starting point, this research considers the text of the international agreement. It then delves into the comparative copyright laws of key participants in the trade agreement. This study also considers the operation of measures such as intermediary liability and technological protection measures in social practice. This analysis draws upon a wide range of sources including international agreements, national legislation, and case law. There is a focus upon law reform inquiries-particularly into the TPP-and submissions of a range of key stakeholders. Digital copyright law reform demands an engagement with international relation, geopolitics, and economics (Haggart 2014). The scholarly field of secondary literature on the TPP is still evolving (particularly after the publication of the official text of the TPP). As well as a traditional engagement with research monographs and academic journal articles, there is also an analysis of blogs on the TPP, particularly by leading stakeholders and policy-makers. As Professor Cass Sunstein has noted, blogs are a rich source of material for analysis, particularly in respect of fast-moving developments (Sunstein 2017). The use of such sources in this paper relies upon quotations from a range of stakeholders to give a sense of the polyphonic, multi-vocal nature of the public policy debate over the TPP.

It is worthwhile also delimiting the scope and the boundaries of this study in terms of its subject matter and its legal geography. The TPP is an ambitious agreement on intellectual property and trade, and is not easily encapsulated in a single essay. This work focuses upon key measures related to the $D M C A$-intermediary liability, technological protection measures, and electronic rights management information. This study does not look at other copyright measures within the TPP such as the copyright term extension, the text on copyright exceptions, and the debate over disability rights. Nor does it chart the civil offences, criminal offences, and border measures contained in the TPP. Likewise, this study does not cover other fields of intellectual property covered by the TPP such as patent law, biologics, trademark law, geographical indications, plant breeders' rights, and trade secrets. There are also significant geographical limitations on the scope of this essay. The TPP includes a dozen nation states, each with their own specific legal, political, and social debates over implementation. This study will focus in particular upon the United States and the $D M C A$, and its translation and adaptation to other key developed nations in the TPP-Australia, Canada, and New Zealand. Other research has considered the adoption of the TPP in Southeast Asia (Nguyen and Elms 2016), and Central and Latin America-Mexico, Peru, and Chile (Duhamel and Bringas 2016). The export of DMCA measures to 
countries in the Asian region also raises larger questions about intellectual property and development. This paper also does not consider the impact of TPP on nation states excluded from the scope of the agreement, such as the BRICS countries (Brazil, Russia, India, China, and South Africa), and Pacific Island States. Such defined parameters to this paper will be helpful in terms of providing a focused analysis of a particularly salient set of features of the TPP related to the DMCA.

In terms of its analysis of the TPP, this paper draws upon the work of Nobel Laureate Joseph Stiglitz on fair trade, intellectual property, and equality (Stiglitz 2012). In 2013, Stiglitz warned that the TPP would undermine progressive law reform in the Pacific Rim by locking national governments into a matrix of standards and obligations: "The TPP proposes to freeze into a binding trade agreement many of the worst features of the worst laws in the TPP countries, making needed reforms extremely difficult if not impossible" (Stiglitz 2013). He elaborated upon such concerns in further work on trade and inequality (Stiglitz and Hersh 2015; Stiglitz 2016a, 2016b; Stiglitz et al. 2016; Baker et al. 2017). Applying the general precepts of Stiglitz to the field of copyright law, the TPP appears designed to freeze into a binding trade agreement many of the worst features of the DMCA in the TPP countries, making needed reforms extremely difficult if not impossible to achieve. The DMCA measures in the TPP will limit and curtail the capacity of Pacific Rim Parliaments to engage in progressive copyright law reform. This paper considers the ambitions of the TPP to use the DMCA as a template for the copyright laws of the Pacific Rim. Part 2 focuses upon intermediary liability. Part 3 examines technological protection measures-especially in light of a constitutional challenge to the DMCA. Part 4 looks at electronic rights management. The conclusion considers the relationship between intellectual property, electronic commerce, and Investor-State Dispute Settlement in the TPP. The combination of such regulatory disciplines could further entrench the position of copyright industries.

It is a timely and prescient moment to evaluate the copyright measures of the TPP because, although the new United States President, Donald Trump, has withdrawn the United States from the negotiations, the remaining 11 countries are still considering the conclusion and the completion of the agreement (The White House 2017; Agence France-Presse 2017). Moreover, the substantive provisions of the TPP look set to become the template for further trade negotiations-such as the revision of NAFTA. ${ }^{4}$

\section{Safe Harbours and Intermediary Liability}

There was heated debate over the language in the TPP on takedown-and-notice, safe harbours, and intermediary liability. In respect of early drafts of the TPP, Kurt Opsahl and Carolina Rossini of the Electronic Frontier Foundation flagged concerns about intermediary liability regime in respect of the agreement (Opsahl and Rossini 2012). They stressed: "By enabling free or low-cost platforms that enable anyone to reach an audience of millions, ISPs have democratized media and enabled innovative ideas to spread quickly—without the gatekeepers of traditional media" (Opsahl and Rossini 2012). The Electronic Frontier Foundation warned in 2012: “The TPP wants service providers to undertake the financial and administrative burdens of becoming copyright cops, serving a copyright maximalist agenda while disregarding the consequences for Internet freedom and innovation" (Opsahl and Rossini 2012). They feared that the regime of internet service provider liability would go beyond the $D M C A$ and the rejected framework in ACTA. The pair were concerned that such a regime would imperil both procedural and substantive standards in respect of due process, fair use, privacy, and free speech.

The United States Trade Representative has been enthusiastic about the final text on copyright law, safe harbours, and intermediary liability:

The Intellectual Property chapter requires Parties to establish copyright safe harbors for Internet Service Providers (ISPs). In the United States, safe harbors allow legitimate ISPs to develop their business, while also helping to address Internet copyright infringement in

4 North American Free Trade Agreement (NAFTA) 199332 ILM 289, 605 (1993). 
an effective manner. Safe harbors have contributed to the flourishing of the most vibrant Internet, entertainment and e-commerce industries in the world. TPP does not include any obligations on these ISPs to monitor content on their networks or systems. TPP also provides for safeguards against abuse of such safe harbor regimes (The United States Trade Representative 2015a).

The United States Trade Representative maintains that the model of the regime will be beneficial for the digital economy in the Pacific Rim.

It is striking that peak information technology bodies-represented by the Computer and Communications Industry Association, the Internet Association, and the Consumer Electronics Association-welcomed the TPP because it preserved the safe harbours regime (Computer and Communications Industry Association 2015; Internet Association 2016; Consumer Electronics Association 2015). In a Faustian pact, the Big IT companies begrudgingly accepted the copyright regime in the TPP in return for the electronic commerce measures in the agreement. However, civil society organisations were not so sanguine about the imperfect regime being installed in the TPP. Professor Joseph Stiglitz has warned of the dangers of the formation of monopolies and the distortion of markets-particularly in respect of telecommunications and internet services (Stiglitz 2012).

\subsection{The Text of the TPP}

Section J of Chapter 18 of the TPP considers the regulation of Internet Service Providers. Article 18.81 provides a definition of an 'internet service provider'. Article 18.82.1 deals with legal remedies and safe harbours, providing that "each Party shall ensure that legal remedies are available for right holders to address such copyright infringement and shall establish or maintain appropriate safe harbours in respect of online services that are Internet Service Providers." Article 18.82.2 elaborates upon a framework of legal remedies and safe harbours. The first limb is "legal incentives for Internet Service Providers to cooperate with copyright owners to deter the unauthorised storage and transmission of copyrighted materials or, in the alternative, to take other action to deter the unauthorised storage and transmission of copyrighted materials. The second limb is "limitations in its law that have the effect of precluding monetary relief against Internet Service Providers for copyright infringements that they do not control, initiate or direct, and that take place through systems or networks controlled or operated by them or on their behalf." The limitations include transmissions, caching, storage, and referring or linking users to an online location.

Article 18.82.3 provides "a requirement for Internet Service Providers to expeditiously remove or disable access to material residing on their networks or systems upon obtaining actual knowledge of the copyright infringement or becoming aware of facts or circumstances from which the infringement is apparent, such as through receiving a notice of alleged infringement from the right holder or a person authorised to act on its behalf." Article 18.82.3 also provides that "an Internet Service Provider that removes or disables access to material in good faith under subparagraph (a) shall be exempt from any liability for having done so, provided that it takes reasonable steps in advance or promptly after to notify the person whose material is removed or disabled."

Article 18.82.4 deals with counter-notices. Article 18.82.5 focuses upon remedies for material representations in respect of notices or counter-notices. Article 18.82 .6 provides that "eligibility for the limitations in paragraph 1 shall not be conditioned on the Internet Service Provider monitoring its service or affirmatively seeking facts indicating infringing activity." Article 18.82.7 states: "Each Party shall provide procedures, whether judicial or administrative, in accordance with that Party's legal system, and consistent with principles of due process and privacy, that enable a copyright owner that has made a legally sufficient claim of copyright infringement to obtain expeditiously from an Internet Service Provider information in the provider's possession identifying the alleged infringer, in cases in which that information is sought for the purpose of protecting or enforcing that copyright." Article 18.82.8 provides the rider: "The Parties understand that the failure of an Internet Service Provider to qualify for the limitations in paragraph 1 (b) does not itself result in liability." Article 18.82.9 notes: 
"The Parties recognise the importance, in implementing their obligations under this Article, of taking into account the impacts on right holders and Internet Service Providers."

The text on intermediary liability is further complicated by a series of marginalia, appendices, and side-letters.

The TPP could entrench the model of intermediary liability in the DMCA across the Pacific Rim (The United States Trade Representative 2015b). The regime favours the interests of legacy copyright industries (Rimmer 2015). Annemarie Bridy has provided an analysis of Section J of the Intellectual Property Chapter of the TPP (Bridy 2015). She observed: “Section J of the TPP's IP chapter, on ISP safe harbors, looks a lot like Section 512 of the DMCA, but the two frameworks differ in some important respects that could negatively impact the global environment for user speech online (Bridy 2015)." Bridy provides a comparison of Section J and Section 512 with a "focus on the rights of users and the status of user expression in the TPP's intermediary safe harbor provisions" (Bridy 2015). Bridy observed: “The TPP's safe harbor provisions differ from the DMCA's, however, in important ways that make the notice and takedown protocol it contemplates structurally less speech-protective and more prone to over-enforcement and abuse" (Bridy 2015). She warned that "the TPP makes it optional for member states to include a counter-notice and put-back protocol in their safe harbor frameworks" (Bridy 2015). She also observed: "Another important difference between the TPP and the DMCA is that the TPP has more relaxed requirements for the contents of a takedown notice" (Bridy 2015).

Wikipedia has long had concern about the impact of copyright law upon its operations (Rimmer 2009). The Wikimedia Foundation had mixed views about the inclusion of the safe harbours regime, and the takedown and notice scheme in the TPP (The Wikimedia Foundation 2016). The group commented that the agreement "states that countries should not require the hosts of sites like Wikipedia to monitor their content for copyright infringement and provides for safe harbors from intermediary liability" (The Wikimedia Foundation 2016). The Wikimedia Foundation thought that the takedown and notice system in the TPP lacked balance because "it lacks a process for counter notices, so that users can push back when a site receives an invalid request to remove content" (The Wikimedia Foundation 2016). In its view, "the vague standards in TPP leave this notice and takedown process open for abuse that can chill speech" (The Wikimedia Foundation 2016). The Wikimedia Foundation has also been concerned that some jurisdictions in the Pacific Rim, like Australia, do not enjoy a broad and flexible defence of fair use (Martin 2017).

There has been significant opposition in the Internet community to the proposed TPP-with the Electronic Frontier Foundation and Cory Doctorow vowing to "kill the TPP" because of their concerns that it would undermine a free and open Internet (Sutton 2015; Doctorow 2015a).

\subsection{United States}

In the United States, it is striking that there has been significant dissatisfaction in respect of the safe harbours regime for the DMCA. Copyright owners have complained to the United States Copyright Office in submissions about the practical operation of s 512 of the DMCA. There was also an unsuccessful attempt to augment the powers of copyright owners, with the Stop Online Piracy Act (Carrier 2013; Moon et al. 2013).

In the wake of defeats in litigation over Google Books ${ }^{5}$ (Rimmer 2017b) and YouTube ${ }^{6}$ (Rimmer 2017a), the copyright industries lobbied for a revision of the DMCA rules in respect of intermediary liability. Entertainment celebrities such Taylor Swift, Paul McCartney, and Kings of Leon have led a

5 The Authors Guild v. Google Inc. 804 F. 3d 202 (2015) United States Court of Appeals, Second Circuit. The Authors Guild v. Google, Inc., 282 F.R.D. 384 (S.D.N.Y. 2012), The Authors Guild v. Google, Inc., 721 F.3d 132, 134 (2d Cir. 2013). The Authors Guild v. Google, Inc., 770 F. Supp. 2d 666 (S.D.N.Y. 2011), and The Authors Guild, Inc. v. Google Inc., 954 F.Supp.2d 282 (S.D.N.Y.2013), and The Authors Guild v. Google Inc., (2016) No. 15-849,

6 Viacom International Inc. and others v. YouTube, Inc. 718 F. Supp. 2d 514 (2010); and Viacom International Inc. and others v. YouTube, Inc. 940 F. Supp. 2d 110 (2013). 
petition for digital copyright reform (Kreps 2016). The high profile stars argue that the DMCA "has allowed major tech companies to grow and generate huge profits by creating ease of use for consumers to carry almost every recorded song in history in their pocket via a smartphone, while songwriters' and artists' earnings continue to diminish." (Kreps 2016). The copyright industries-and their high profile stars-hope to encourage the United States Copyright Office and the United States Congress to revise the norms of the DMCA (Snider 2016). The multinational copyright owners have even added Netflix to their grand global alliance aimed at fighting copyright infringement (Spangler 2017).

In this context of this controversy over whether the $D M C A$ will be updated, it is most peculiar that the TPP is seeking to entrench key features of the DMCA.

There remains concerns about the impact of the takedown and notice system upon Internet users, citizens, and users. The epic 'Dancing Baby' copyright litigation has highlighted concerns about the relationship between the takedown and notice system and the defence of fair use (Rimmer 2017a). ${ }^{7}$ The Supreme Court of the United States has declined to become involved in the 'Dancing Baby' copyright litigation (Gardner 2017). ${ }^{8}$

Major empirical research on the DMCA takedown and notice system by Jennifer Urban and her colleagues highlights the need for reform (Urban et al. 2016). Urban and her colleagues are concerned by the rise of automated, 'bot' based systems to address copyright infringement, which leave little room for human judgment and assessment. The study reveals a disturbingly high number of take-down requests of dubious validity. The research raises concerns about the effects of copyright takedown abuse on online free expression (Doctorow 2016a). There has been pressure upon the United States Congress and the Copyright Office to reform the system (Masnick 2016a). The copyright industry have quibbled about the report, with the MPAA and RIAA commissioning a critique (Ford 2017). Jennifer Urban and her colleagues have defended the validity of their findings against such criticism (Urban et al. 2017).

Annemarie Bridy and Daphne Keller have also provided a lengthy analysis of whether the section 512 safe harbours regime of the DMCA is working as intended (Bridy and Keller 2016).

In policy circles, there has been a call for better legal frameworks to address copyright law and intermediary liability (Pappalardo 2014; Hunter and Suzor 2015).

Cory Doctorow observed that not every country made the same mistakes as the United States in respect of intermediary liability. He noted that "countries like Chile, Japan and Canada created versions of the DMCA that have checks and balances-review by experts, court orders, or the right to rebut claims before material is taken down" (Doctorow 2015b). Doctorow lamented: "the secretive $T P P$, pushed by the US trade representative and negotiated between 12 countries says that signatories musn't change their copyright system to match the Japanese, Canadian or Chilean models: any future copyright reform must bring rules in line with the US system-to race with America straight to the bottom of the Internet regulation heap, the lawless land of unfettered and unaccountable censorship" (Doctorow 2015b). He argued that the template of the DMCA is a poor model to emulate for other countries in the Pacific Rim.

Technology companies have been concerned about how the agreement will affect their operations. Erik Martin, the general manager of reddit, said: "We oppose Fast Track for the TPP because it's an undemocratic agreement that threatens the open Internet" (Dreams 2014). There remains heated debate over the operation of the DMCA provisions on safe harbours. Reports of the s 512 roundtable of the United States Copyright Office give a sense of the wide spectrum of competing views on the topic (Tushnet 2016). Given the raging policy debate over the DMCA almost twenty years after its enactment, it is most peculiar that such a model should be used as a template for the TPP. As Jeremy Malcolm comments, the TPP perpetuates the mistakes of the DMCA (Malcolm 2015).

\footnotetext{
Lenz v. Universal Music Corporation 2015 WL 5315388 (C.A.9 (Cal.)).

Lenz v. Universal Music Corporation-Petition for certiorari denied 19 June 2017
} 


\subsection{Canada}

In contrast to the United States with its take-down and notice scheme, Canada has established a notice-and-notice approach to copyright law and intermediary liability. The compatibility of Canada's laws with the TPP was debated in the Canadian parliamentary inquiry (Standing Committee on International Trade 2017).

Professor Michael Geist observed that a compromise in the TPP negotiations enabled Canada to retain its notice-and-notice system:

The TPP compromise allows Canada to maintain the notice-and-notice system, but no other TPP member country can adopt it in order to comply with the ISP liability and notice rules in the intellectual property chapter. The Canadian rules can be found in Annex 18-E of the intellectual property chapter, which states that the standard ISP rules in the agreement do not apply to a country that meets the conditions of the annex 'as from the date of agreement in principle of this Agreement'. Since that date is now long passed (4 October 2015), no other TPP country can implement the notice-and-notice system to meet its TPP obligations (Geist 2016c).

Geist also noted that Chile had obtained a similar exception for its system based on Annex 18-F of the U.S.-Chile Free Trade Agreement. He observed that such compromises highlighted a key source of trouble in the TPP: "More than a mere trade agreement, the TPP is a clear effort by the U.S. to export its regulatory framework to other countries, creating a competitive advantage for U.S. companies." (Geist 2016c, p. 167).

Howard Knopf has argued that there is a need for Canada to preserve notice-and-notice system in further trade negotiations (Knopf 2017). Moreover, in the wake of the Voltage litigation, ${ }^{9}$ he argues that "the government can and must implement regulations that forbid the inclusion of extraneous 'settlement demands' in any such notices, or at least require the inclusion of prominent language informing the recipient of their right to simply not respond to the notice in any way and to ignore any settlement demand" (Knopf 2017). He also recommends that "the government can also use its regulatory power to set maximum fees, so that ISPs can be reimbursed by copyright owners for the costs involved in complying with court-ordered disclosures of customer identities" (Knopf 2017).

\subsection{Australia}

In Australia, there has been a fierce debate over copyright law and intermediary liability. In 2012, the High Court of Australia considered an action by Roadshow against the internet service provider, iiNet, alleging authorisation of copyright infringement. ${ }^{10}$ French CJ, Crennan, and Kiefel JJ commented:

The appellants' submission, that iiNet should be taken to have authorised the infringements unless it took measures with respect to its customers, assumes obligations on the part of an ISP which the Copyright Act does not impose. A consideration of the factors listed in $\mathrm{s}$ $101(1 \mathrm{~A})$ does not permit a conclusion that iiNet is to be held liable as having authorised the infringements.

The extent of iiNet's power was limited to an indirect power to prevent a customer's primary infringement of the appellants' films by terminating the contractual relationship between them. The information contained in the AFACT notices, as and when they were served, did not provide iiNet with a reasonable basis for sending warning notices to individual customers containing threats to suspend or terminate those customers' accounts. For these reasons, iiNet's inactivity after receipt of the AFACT notices did not give rise 
to an inference of authorisation (by "countenancing" or otherwise) of any act of primary infringement by its customers. ${ }^{11}$

The judges noted that "the concept and the principles of the statutory tort of authorisation of copyright infringement are not readily suited to enforcing the rights of copyright owners in respect of widespread infringements occasioned by peer-to-peer file sharing, as occurs with the BitTorrent system." ${ }^{12}$ The judges commented that "the difficulties of enforcement which such infringements pose for copyright owners have been addressed elsewhere, in constitutional settings different from our own, by specially targeted legislative schemes, some of which incorporate co-operative industry protocols, some of which require judicial involvement in the termination of internet accounts, and some of which provide for the sharing of enforcement costs between ISPs and copyright owners." ${ }^{\prime 3}$

In the wake of this litigation, there has been a particular concern amongst information technology companies that the beneficiaries of the safe harbours regime have been limited to telecommunications networks and internet service providers. Other new intermediaries-such as search engines, social media, big data sites, and cloud computing services-do not necessarily benefit from such provisions.

An exposure draft of the bill to amend the Copyright Act to extend safe harbour provisions to schools and universities and other intermediaries was released in 2015.

In its 2016 inquiry into Australia's intellectual property arrangements, the Productivity Commission considered the issue of copyright law and intermediary liability (Productivity Commission 2016a; 2016b). The Productivity Commission considered the competing submissions on the topic from the copyright industries, telecommunications carriers, internet service providers, social media companies, and educational institutions. The Productivity Commission concluded:

In the Commission's view, extending the coverage of Australia's safe harbour regime, along the lines proposed in the Australian Government's exposure draft amendments, will improve the system's adaptability as new services are developed. Such an expansion is consistent with Australia's international obligations and is an important balance to the expanded protections for rights holders Australia has accepted as part of its international agreements. As such this is a legislative amendment that should be made without delay (Productivity Commission 2016b, p. 567).

In recommendation 19.1, the Productivity Commission concluded that "the Australian Government should expand the safe harbour scheme to cover not just carriage service providers, but all providers of online services." (Productivity Commission 2016b, p. 567).

In its report into the TPP, the Joint Standing Committee on Treaties considered the question of copyright law, intermediary liability, and safe harbours (The Joint Standing Committee on Treaties 2016). The Committee was disturbed by the limitations of Australia's safe harbours provisions, noting:

The Copyright Advisory Group argues that the introduction and passage of this Bill should be a priority to ensure Australia complies with the TPP prior to the TPP coming into effect. When this issue was raised with the Australian Government, witnesses from the Department of Communications and the Arts noted that the United States had not raised the issue of Australia's compliance with the AUSFTA safe harbours provisions. ${ }^{14}$ The problem is an Australian one. The fact that the issues raised during the inquiry in relation to safe harbours provisions has reached the stage of being addressed in a draft Bill would indicate to the Committee that the problem is real. The Committee recommends the Australian Government progress the safe harbours amendments to the Copyright Act (The Joint Standing Committee on Treaties 2016, p. 70).

11 Roadshow Films Pty Ltd v. iiNet Ltd. [2012] HCA 16 (20 April 2012).

12 Roadshow Films Pty Ltd v. iiNet Ltd. [2012] HCA 16 (20 April 2012).

13 Roadshow Films Pty Ltd v. iiNet Ltd. [2012] HCA 16 (20 April 2012).

14 Australia-United States Free Trade Agreement (AUSFTA), signed 18 May 2004 (entered into force 1 January 2005). 
As its fourth recommendation, the Committee recommended that "the Australian Government progress the safe harbours amendments in the proposed Copyright Amendment (Disability and Other Access Measures) Bill 2016 (Cth)" (The Joint Standing Committee on Treaties 2016, p. 71).

In its inquiry into the TPP, the Australian Senate Foreign Affairs, Defence, and Trade Committee (Senate Foreign Affairs, Defence, and Trade References Committee 2017) considered the obligations in relation to copyright law. The Committee noted that the Law Council also disputed the NIA's statement that Australia's TPP obligations were consistent with Australia's existing intellectual property regime and require legislation changes. The Committee was conscious of the Law Council's submission that there were a number of areas including online service provider liability where amendments to Australian law may be required.

In March 2017, the Coalition Government decided to remove the safe harbours provisions from the legislative bill. The Minister for Communications, Senator Mitch Fifield (2017), commented that the "provisions relating to safe harbour were removed from the bill before its introduction to enable the Government to further consider feedback received on this proposal whilst not delaying the passage of other important reforms." This seemed to be the result of divisions within the Coalition Government in terms of the Cabinet, and the Caucus.

The startup technology community was incensed at the lack of progress on the issue of safe harbours protection. Martin Hosking of Redbubble commented: "The government is asking for innovation from corporations, but the government has to show that same level of innovation" (Swan 2017). Redbubble local legal counsel Paul Gordon warned: "The relative uncertainty in Australia makes Redbubble a far more likely target in litigation, even if it's litigation that has no particularly strong merits" (Swan 2017).

In March 2017, the Hon. Ed Husic MP (Husic 2017, p. 66)—the Australian Labor Party's Member for Chifley in the House of Representatives-was critical of the failure of the Coalition Government to reform the laws with respect to safe harbours. He commented that "an inability to have an effective safe-harbour regime in this country—-which was supposed to be in this bill-means that jobs are on the line." Husic argued that "we are looking at a government that championed itself as being the innovation government, the one that would see all these new firms sprout up, particularly in the tech space." He observed that "these firms are now actively looking to go overseas because this bill—and the policy cowardice that is wrapped up in this bill-was unable to work out a way to allow those firms to continue in this country."

To illustrate his concerns, Husic highlighted the example of Redbubble in Australia, noting that "their commercial prospects have been put under pressure because of the policy cowardice of this government". Husic noted that Redbubble had an artist who developed an image that incorporated a logo of another organisation-the Hells Angels. The Hells Angels brought action against Redbubble in Australia, but Redbubble was unable to avail itself of safe harbours protection. Husic observed: "so firms like Redbubble, Envato and 99designs are all under legal pressure because the cowards opposite were unable to find a way to ensure this survives." Husic observed: "Martin Hosking has threatened to pull his ASX listed company out of Australia—this is insane-because the country's copyright laws are not reformed." He noted that Martin Hosking had said that without safe harbour protections they will have to leave.

Husic concluded: "We risk losing great businesses like these-Redbubble—and stifling the growth of others, if we don't develop a strong safe harbour framework such as they have in the US, Singapore, the UK and other EU countries." He implored the Coalition Government: "if Australia wants to transition to become a digital economy, we must catch up with the rest of the world on how we treat online copyright content."

In the end, the Copyright Amendment (Disability and Other Access Measures) Act 2017 (Cth) was passed through the Australian Parliament-but without any reforms in respect of safe harbours in Australia. 
In addition to questions about safe harbours, there has also been larger issues about internet service providers and their consumers.

There has been significant civil litigation in respect of the film The Dallas Buyers Club across the Pacific Rim —with actions in Canada, the United States, and Singapore (Parker 2014; Tham 2015; Geist 2016b). In Australia, the courts took care to provide strong management of the copyright owners' demands. ${ }^{15}$ The Dallas Buyers Club was defeated (Swan 2015; Grubb and Whitbourn 2015; Burgess 2015; Whitbourn 2015; Crozier 2015). The action was abandoned in 2016 (Sheppard 2016). There has also been the threat of legal action over The Dallas Buyers Club in New Zealand (Pullar-Strecker 2015). There have been further conflicts over ownership of the movie (Ernesto 2016). The Dallas Buyers Club's litigation has raised concerns about the use of speculative invoicing in relation to copyright matters. Such disputes raised issues about the inter-relationship between copyright law, privacy, and consumer rights. The TPP does not adequately address the question of the abuse of copyright.

The proposal for an industry copyright code governing the relationship between copyright owners, internet service providers, and end users in Australia seems to have collapsed (Francis 2016).

Some countries have already passed ahead with measures above and beyond what is providing for by the TPP. Famously, in the United States, the Stop Online Piracy Act was rejected because of concerns about its impact on internet freedom (Black 2011; Moon et al. 2013). One of the most controversial features of the bill was the foreign site-blocking power. Despite this setback, copyright owners have lobbied other jurisdictions for site-blocking powers. Under the leadership of the Hon. Tony Abbott, the Australian Parliament passed the Copyright Amendment (Online Infringement) Act 2015 (Cth). This legislation provides the extraordinary power of enabling copyright owners to ask the Australian Courts for the remedy of site-blocking. There has been concern about the political lobbying for the power by copyright owners such as Roadshow and Foxtel (Coyne 2015). The design of the legislative regime raises larger questions about the impact of such a power upon an open and free Internet (Hunter 2014). There have already been a couple of test cases brought by copyright owners in respect of site-blocking-one has focused upon SolarMovie, and the other has looked at Kickass Torrents (Mason 2016). Not surprisingly, copyright owners have fared successfully in respect of the use of the site-blocking regime. The Federal Court of Australia has handed down a couple of decisions on the use of the site-blocking power (Coyne 2015). ${ }^{16}$

In June 2017, there were further reports that Foxtel was seeking Federal Courts to require Australia's largest internet service providers to block 17 internet sites (Pearce 2017). The film industry and the music industry would like other jurisdictions in the Pacific Rim to provide for site-blocking powers.

\subsection{New Zealand}

In New Zealand, there was an early introduction of a graduated response scheme in respect of copyright law and intermediary liability—the Copyright (Infringing File Sharing) Amendment Act 2011 (NZ). The scheme has been popularly dubbed 'Skynet' in honour of the Terminator films.

During the parliamentary debate, there was much discussion about whether the approach was appropriate. Dr Wayne Mapp (Mapp 2011) of the New Zealand Government commented: "It is important in law that we provide appropriate protection for creative industries so that they can continue to provide jobs for New Zealanders and continue to contribute to our economy." The Hon. Clare Curran (2011) of the New Zealand Labor Party noted: "We support [the bill], but we have serious reservations about suspension of Internet accounts as a penalty." Hughes (2011) of the New Zealand Greens opposed aspects of the regime, observing: "We support Kiwi rights-holders and Kiwi artists,

15 Dallas Buyers Club LLC v iiNet Limited [2015] FCA 317.

16 Roadshow Films Pty Ltd v. Telstra Corporation Ltd [2016] FCA 1503 (15 December 2016); and Universal Music Australia Pty Limited v. TPG Internet Pty Ltd [2017] FCA 435. 
and we think the use of notices and fines, rather than Internet suspension, is a more appropriate and proportionate sanction for file sharing." He stressed: "access to the Internet is vital for engagement with our modern world, and the Green Party will have no part in legislating it away from the people." Some early test cases have addressed the three strikes scheme adopted in New Zealand. ${ }^{17}$

An expert New Zealand report consider the current relationship between New Zealand copyright law and the TPP (Ting-Edwards et al. 2016). The report observed:

Current New Zealand law provides a 'graduated response' regime. Service providers are protected from copyright liability where they remove alleged infringing content, and where they pass infringement notices on to users. The TPPA provides a broadly similar framework. As with other areas, measures favouring rights-holders are mandatory, and those offering balance are optional. Unlike earlier drafts, the TPPA does not require that 'repeat infringers' be banned from a service, a move which would have paralleled the controversial, now-repealed s 92A of New Zealand's Copyright Act 1994. As it stands, New Zealand's current regime is likely at the user-favourable end of what the TPPA would allow (Ting-Edwards et al. 2016).

There remains an uneasy debate over the graduated response regime in New Zealand, with none of the stakeholders particularly satisfied with the operation of the regime (Pullar-Strecker 2012).

At a larger scale, there has been well-documented controversy over a provider of cloud computing services. The messy, complicated case of Kim Dotcom and Megaupload in New Zealand has attracted much attention (Reuters and AAP 2015; Fisher 2013; Palmer and Warren 2013). ${ }^{18}$ The United States Government has sought to extradite Kim Dotcom to the United States on copyright charges. Professor Lawrence Lessig has expressed qualms about the extradition (Lessig 2015). At the time of writing, the New Zealand district court had approved the extradition of Kim Dotcom. Kim Dotcom appealed this decision.

The Minister of Commerce and Consumer Affairs of the New Zealand Government has announced a new copyright review in 2017. The background paper to the announcement noted:

Aspects of the current regime are now out of date. Rapid technological change has resulted in significant changes in creative content delivery markets and the way that content is used. For example 'streaming', which is now a key content delivery mechanism, had only just emerged during the last review. Other examples include uses of big data and cloud storage (Ministry of Business, Innovation, and Employment, New Zealand Government 2017).

The New Zealand Government appears to recognise that there remain challenges in terms of modernising its copyright regime.

\subsection{Summary}

The lack of harmonisation of copyright rules on intermediary liability in the Pacific Rim is a real and immediate problem. Thus the TPP holds out the promise achieving greater procedural and substantive harmonisation. However, the DMCA rules on copyright law, safe harbours, and intermediary liability were crafted in an early era of information and communications technologies. There has been concern about the automation of takedown and notice requests, and the operation of online intermediaries. Niva Elkin-Koren has reflected upon changes in the digital ecosystem:

Access to creative works is made possible by online intermediaries, using algorithms to filter, block, and disable access to copyrighted materials. Access is often subject

\footnotetext{
17 Recording Industry Association NZ Inc. v. Telecom NZ 3553 [2013] NZCopyT 6 (16 April 2013); and Recording Industry Association New Zealand v. Telecom NZ 4296 [2013] NZCopyT 10; [2013] NZCOP 10 (16 July 2013).

18 Twentieth Century Fox Film Corporation v. Dotcom [2015] NZHC 3349.
} 
to monitoring and surveillance. The robustness of algorithm filtering, removal, and blocking practices is effectively changing the copyright default: Copyrighted materials were once available unless proven infringing, while now materials detected by algorithms are unavailable unless explicitly authorized by the copyright owner (Elkin-Koren 2017).

Such measures have been increasingly strained by a host of new developments, including Big Data, cloud computing, search engines, and social media. The regime does not seem fit for purpose for a future Internet of Things. In the United States, copyright stakeholders have been expressing dissatisfaction over the operation of the DMCA regime.

Given the range of public policy issues in respect of intermediary liability, it seems unwise to entrench the DMCA across the Pacific Rim through the device of the TPP. The United States DMCA does not necessarily seem to be an ideal model to be emulated by countries such as Canada, Australia, and New Zealand - let alone by some of the developing countries and the least developed countries in the Pacific Rim. The Manila Principles on Intermediary Liability have sought to provide a best practice model for dealing with such questions surrounding the liability of intermediaries in respect of communication on the internet (Electronic Frontier Foundation 2015). This could be a much more flexible and adaptable regime for intermediary liability than that dictated by the TPP.

\section{Technological Protection Measures}

Building upon the WIPO Internet Treaties, The United States Trade Representative (2015c) has sought to promote highly complex, prescriptive provisions on technological protection measures and electronic rights management in the TPP. The DMCA is the template for the regime. As Timothy Lee noted: "The treaty includes a long section, proposed by the United States, requiring the creation of legal penalties for circumventing copy-protection schemes such as those that prevent copying of DVDs and Kindle books" (Lee 2013).

Anissa Brennan, the Senior Vice President for International Affairs for the Motion Picture Association of America, was delighted by the provisions on technological protection measures: "Specifically, the TPP includes protections for technological protection measures, which allow creators to control access to their works and, in so doing, enable the functionality of online business models, contributing to the expansion of digital offerings for viewing movies and TV shows" (Brennan 2016).

However, there has been wider disquiet about the impact of technological protection measures and electronic rights management systems. Professor Joseph Stiglitz has been particularly concerned about the impact of intellectual property rent-seeking on consumer rights and competition policy (Stiglitz 2012). This has been a particular problem in respect of the use and abuse of technological protection measures in the marketplace.

\subsection{Text of the TPP}

Article 18.68 of the TPP addresses the topic of technological protection measures. It is worth reproducing the text in full to give sense of the complex, prescriptive, and over-elaborate wording of the provision. Article 18.68.1 provides an expansive definition of technological protection measures. Article 18.68.2 provides that "in implementing paragraph 1, no Party shall be obligated to require that the design of, or the design and selection of parts and components for, a consumer electronics, telecommunications, or computing product provide for a response to any particular technological measure, provided that the product does not otherwise violate a measure implementing paragraph 1." Article 18.68.3 provides: "Each Party shall provide that a violation of a measure implementing this Article is independent of any infringement that might occur under the Party's law on copyright and related rights."

Article 18.68.4 of the TPP describes the limited exceptions available for technological protection measures.

Article 16.68.5 provides a definition that an "effective technological measure means any effective technology, device, or component that, in the normal course of its operation, controls access to a 
protected work, performance, or phonogram, or protects copyright or related rights related to a work, performance or phonogram." This is a broad, expansive definition. This may prevent courts from seeking to delimit the definition of technological protection measures-like the High Court of Australia in Stevens v. Sony. ${ }^{19}$

\subsection{United States}

The DMCA regime introduced new protections in respect of technological protection measures. There has been major litigation in the United States over this regime (Gillespie 2017). There has also been public policy debate in roundtables hosted by the United States Copyright Office on the operation of technological protection measures (United States Copyright Office 2017b). There have been significant conflicts in respect of original equipment manufacturers seeking to block competitors from entering into the marketplaces in respect of products such as printer cartridges, ${ }^{20}$ garage openers, ${ }^{21}$ tape cartridge libraries, ${ }^{22}$ and prepaid phone cards. ${ }^{23}$ More recently, there have even been high profile controversies over the agricultural machinery giant, John Deere, trying to invoke digital rights management and technological protection measures in respect of its products (Deere 2015; Wiens 2015a, 2015b; Sydell 2015).

Aaron Perzanowski and Jason Schultz consider the history of technological protection measures in their book, The End of Ownership: Personal Property in the Digital Economy (Perzanowski and Schultz 2016). They observe that the DMCA regime has failed to achieve its stated goals:

Even from the perspective of copyright holders, the $D M C A^{\prime}$ 's anti-circumvention provisions would be charitably described as a mixed bag. And from the perspective of the public, the DMCA has been an unmitigated disaster. It has jeopardized their privacy and security, impeded innovation and encouraged lock-in, and paved the way for an unprecedented loss of control over the devices they own (Perzanowski and Schultz 2016, p. 132).

Aaron Perzanowski and Jason Schultz contend that such technological protection measures will be even more problematic in the age of the Internet of Things. They quip that it will be an era of "The Internet of Things You Don't Own" (Perzanowski and Schultz 2016, p. 139).

In the Apollo 1201 project, Cory Doctorow has joined with the Electronic Frontier Foundation to eradicate digital rights management systems (Electronic Frontier Foundation 2015). Parker Higgins has expressed concern about how the regime will "have profound chilling effects on hackers, makers, and tinkerers" (Higgins 2013). He warns of the dangers posed by technological protection measures:

The problems for hackers and makers stem from the so-called 'anti-circumvention' rules that have appeared in leaked drafts of the agreement. That language reflects a controversial clause of U.S. copyright law that makes it illegal to bypass technical measures that are put in place to restrict copyrighted content-such as measures that limit the number of devices on which you can play a video you legally purchased (Higgins 2013).

Higgins feared: "Even if you are bypassing those restrictions for reasons that don't violate copyright law-say you're remixing a segment of a video under fair use rules, or trying to read an ebook on a different platform-you could still get caught in the anti-circumvention net" (Higgins 2013). He concluded: "The TPP would make the situation worse by locking anti-circumvention rules in place in the countries that already have them, and expanding them to the ones that don' $t^{\prime \prime}$ (Higgins 2013). In his view, the "TPP would be a disaster for the Internet and innovation, and continue a terrible trend of secrecy in negotiations" (Higgins 2013).

19 Stevens v Kabushiki Kaisha Sony Computer Entertainment [2005] HCA 58.

20 Lexmark International, Inc. v. Static Control Components, 387 F.3d 522 (6th Cir. 2005).

21 Chamberlain Group, Inc. v. Skylink Technologies, Inc., 381 F.3d 1178 (Fed. Cir. 2004).

22 Storage Technology Corporation v. Custom Hardware Engineering E Consulting, Inc., 421 F.3d 1307 (Fed. Cir. 2005).

23 Tracfone Wireless, Inc. v. Anadisk LLC, 685 F. Supp.2d 1304 (S.D. Fla. 2010). 
In July 2016, a constitutional challenge was launched by Matthew Green, Andrew ‘Bunnie' Huang, and Alphamax LLC against the technological protection measures regime in the DMCA (Electronic Frontier Foundation 2016). The challenge was brought by the digital rights defenders, the Electronic Frontier Foundation. The complaint explains the nature of the challenge:

This lawsuit challenges the 'anti-circumvention' and 'anti-trafficking' provisions of the [DMCA]. Enacted in 1998, these provisions broadly restrict the public's ability to access, speak about, and use copyrighted materials, without the traditional safeguards—such as the fair use doctrine- that are necessary to protect free speech and allow copyright law to coexist with the First Amendment. The threat of enforcement of these provisions chills protected and non-infringing speech that relies on copyrighted works, including independent technical research into computer security systems and the discussion of that research, and accessing copyrighted works in order to shift the content to a different format, space, or time (Electronic Frontier Foundation 2016, p. 1).

The Electronic Frontier Foundation was concerned that the triennial rulemaking process by which the public may seek exemptions did not alleviate these problems. Indeed, the civil society organisation protested: "To the contrary, the rulemaking is itself an unconstitutional speech-licensing regime." (Electronic Frontier Foundation 2016, p. 1).

Andrew 'Bunnie' Huang explained his motivations behind the lawsuit (Huang 2016). He lamented that Section 1201 of the DMCA was problematic: "Section 1201 means that you can be sued or prosecuted for accessing, speaking about, and tinkering with digital media and technologies that you have paid for". He observed: "This violates our First Amendment rights, and I am asking the court to order the federal government to stop enforcing Section 1201". Huang complained that the regime of technological protection measures had a chilling effect on innovation and creativity: "especially now that cryptography pervades every aspect of modern life, every creative spark is likewise dampened by the chill of Section 1201". He lamented that "the act of creation is no longer spontaneous." Huang elaborated upon his concerns:

Our recent generation of makers, hackers, and entrepreneurs have developed under the shadow of Section 1201. Like the parable of the frog in the well, their creativity has been confined to a small patch, not realizing how big and blue the sky could be if they could step outside that well. Nascent 1201-free ecosystems outside the US are leading indicators of how far behind the next generation of Americans will be if we keep with the status quo. Our children deserve better.

Huang commented: "I was born into a 1201-free world, and our future generations deserve that same freedom of thought and expression". He observed: "I am but one instrument in a large orchestra performing the symphony for freedom, but I hope my small part can remind us that once upon a time, there was a world free of such artificial barriers, and that creativity and expression go hand in hand with the ability to share without fear."

Kit Walsh of the Electronic Frontier Foundation has discussed the constitutional issues associated with technological protection measures. He comments: "Section 1201 of the DMCA forbids a wide range of speech, from remix videos that rely upon circumvention, to academic security research, to publication of software that can help repair your car or back up your favourite show" (Walsh 2016).

Parker Higgins observed that the regime "potentially implicates the entire range of speech that relies on access to copyrighted works or describes flaws in access controls-even where that speech is clearly non-infringing" (Higgins 2016). He commented about the conflict between technological protection measures and copyright law: "As long as circumvention in furtherance of fair use risks civil damages or criminal penalties, Section 1201's barrier to non-infringing uses of copyrighted works oversteps the boundary set by the Supreme Court". Higgins argued that "in First Amendment terms, the law is facially overbroad and therefore unconstitutional". He observes: "By preventing valuable 
and non-infringing speech, it goes far beyond any restriction that might be justified by the purposes of copyright law". In his view, the rule-making regime in respect of technological protection measures has been proven to only provide limited and narrow exceptions in respect of technological protection measures. Higgins comments: "Section 1201 is a draconian and unnecessary restriction on speech and the time has come to set it aside". He concludes that "the future of cultural participation and software-related research depends on it".

Higgins has also detailed a number of the other dimensions of technological protection measures (Higgins 2016). He commented: "Someday, your life may depend on the work of a security researcher". Higgins observed: "Whether it's a simple malfunction in a piece of computerized medical equipment or a malicious compromise of your networked car, it's critically important that people working in security can find and fix the problem before the worst happens." He lamented: "Section 1201 means that you can be sued or even jailed if you bypass digital locks on copyrighted works—from DVDs to software in your car-even if you are doing so for an otherwise lawful reason, like security testing". Higgins also notes that such measures also impact upon education, creative arts, and remix culture:

Section 1201's speech restrictions also apply to scholars, artists, and activists that are seeking to comment on culture or make it more accessible. The tools to make engaging remixes, annotations, or interactive commentaries are in the hands of more and more people, but the law has created a 'gotcha' situation: while using that source material is legal, getting access to it might run afoul of these additional legal hurdles.

Higgins noted: "When Congress passed Section 1201, the hot-button copyright debates were about the terms under which people could copy and consume music, movies, and books". He observed that "copyright law shouldn't be casting a legal shadow over activities as basic as popping the hood of your own car, offering commentary on a shared piece of culture (and helping others do so), and testing security infrastructure". Higgins stressed: "It's time for the courts to revisit Section 1201, and fix Congress's constitutional mistake".

Digital rights activist Cory Doctorow has detailed the constitutional challenge in The Guardian, and discussed the international implications of the dispute (Doctorow 2016b). He highlights how the challenge is not only important for the United States, but for other countries, which have been forced to adopt such a regime: "if they succeed, one of America's most controversial technology laws will be struck down, and countries all over the world who have been pressured by the US trade representative to adopt this American rule will have to figure out whether they'll still enforce it, even after the US has given up on it" (Doctorow 2016b). That would apply to countries like Australia and Singapore, which were required to adopt a technological protection measures regime as part of bilateral agreements with the United States. The participants involved in the TPP would be required to adopt the draconian regime for technological protection measures as well.

While sympathetic to the case, Mike Masnick wonders how the constitutional challenge will fare, given the past approach of the Supreme Court of the United States to intellectual property and the First Amendment: "unfortunately, our courts have been incredibly (and unfortunately) reluctant to seriously consider constitutional challenges to copyright law" (Masnick 2016b). There are some important statements in constitutional cases-like Eldred v. Ashcroft ${ }^{24}$ —about the importance of safety-valve clauses, like the ideas / expression dichotomy and the defence of fair use, in the doctrine of copyright law. There has been a long tradition of academic writing that raises concerns about the impact of the DMCA upon freedom of speech and expression.

The United States Copyright Office released its report on technological protection measures in June 2017 (United States Copyright Office 2017c). The Electronic Frontier Foundation lamented that the United States Copyright Office only offered limited, narrow reforms (Stoltz 2017). Mitch Stoltz of

24 Eldred v. Ashcroft 537 U.S. 186 (2003). 
the civil society organisation noted: "The Office does recommend that Congress enact some narrow reforms aimed at protecting security research, repair activities, and access for people with disabilities" (Stoltz 2017). He was frustrated by the lack of a systematic approach to law reform: "It's too bad the Copyright Office won't address the fundamental flaws of Section 1201, especially given the multitude of problems that the report acknowledges" (Stoltz 2017). Cory Doctorow was critical of the study (Doctorow 2017b). He complained that "the report's recommendations fall far short of the minimum standard that the Copyright Office should aspire to, namely: allowing Americans to use their property in lawful ways, even if some corporation wishes they wouldn't, because it hopes to sell them expensive parts, service, apps, or other add-ons" (Doctorow 2017b).

In this context, it is concerning that the TPP embeds the constitutionally dubious technological protection measures into the agreement. The privacy company, NordVPN (2016), has raised concerns about the impact of the TPP for internet freedom and privacy. Obviously, the company has been worried about how private virtual networks will be treated in such a regime.

At a meta-level, Professor Tim Wu of Columbia University has been debating with Tim Berners-Lee the relative merits of technological protection measures (Doctorow 2017a). Wu has warned that anti-circumvention laws have a history of being used for purposes different than the original intent of protecting copyright content. He has contended: "Given the power of those laws, the potential for anti-competitive consequences certainly exists." In this context, there have been larger concerns about the need to keep a free and open Internet in terms of its architecture (Finley 2016).

\subsection{Canada}

There has been a long history of debate over the introduction of technological protection measures in Canada.

Professor Carys Craig has highlighted the digital threat posed by digital locks to the defence of fair dealing and other copyright exceptions by making such measures ineffectual (Craig 2011). She maintained: "In order to ensure that fair dealings and other permitted acts are not only lawful on the books but possible in practice, digital copyright laws should establish positive obligations for rightsholders to facilitate fair and lawful dealings with TPM-protected works" (Craig 2011, p. 190).

The documentary film-maker Brett Gaylor has expressed his concerned about the impact of digital locks upon creativity in Canada (Gaylor 2015). He commented:

Canada has some of the toughest laws to stop you from circumventing things like copy protection on DVDs. The laws don't stop people from making backup copies of movies they've bought, but they do put roadblocks in my way as I'm trying to edit content into my documentaries, creating massive uncertainty about what I can and can't put into a movie (Gaylor 2015).

Such concerns were exacerbated by the proposed regime for digital locks in the TPP.

From a Canadian perspective, Michael Geist has been concerned about the proposed regime for technological protection measures under the TPP, and the narrow, limited nature of exceptions for technological protection measures (Geist 2016a). He lamented:

The TPP does not include an exception for private purposes circumvention. Rather as noted above, it requires either statutory damages or additional damages. Statutory damages are not available in this case and the additional damages available in Canada are not as broad as those required by the TPP. This would suggest that the Canadian private purposes circumvention rule could be challenged with demands that Canada implement new damages requirements for individuals who circumvent a digital lock, even for personal purposes (Geist 2016a).

In his view, the regime was insufficiently flexible to accommodate consumer rights under copyright law. 
In 2017, there was a new precedent in the Federal Court of Canada in respect of the prohibitions against circumventing technological protection measures and trafficking in circumvention devices-Nintendo of America Inc. v Jeramie Douglas King and Go Cyber Shopping (2015) Ltd. ${ }^{25}$ The case concerns the reforms introduced by Canadian Parliament with the Copyright Modernization Act SC 2012 C-42 (Canada). In this matter, the famous video company, Nintendo of America Inc., brought a legal action against an Ontario corporation, which operated a store in Waterloo, and also hosted several commercial websites. The corporation carried out its business under the name 'Modchip Central Ltd.' .

In this precedent, Campbell J. observed that "Parliament explicitly recognized the importance of TPMs for protecting copyrighted works, particularly in the video game industry." 26 The judge considered a number of issues. Campbell J. first explored whether the respondent had infringed Nintendo's copyright works. Moreover, the judge then investigated whether the respondent had contravened the anti-circumvention provisions under the Act. Finally, Campbell J. considered what, if any, remedies were appropriate.

First, Campbell J. recognised that copyright subsisted in the 585 Nintendo Games at issue. Furthermore, the judge found that copyright subsisted in three Header Data Works-including the Nintendo DS Header Code, the Nintendo 3DS Startup Sequence, and the Game Boy Advance Boot Code with Nintendo Logo Data File. The judge observed that Nintendo of America Inc. was the owner of copyright in the Nintendo Games and Header Data Works. Campbell J. ruled that Go Cyber Shopping (2005) Ltd. had infringed the applicant's copyright in the Header Data Works. Campbell J. held that "the Respondent's authorization of infringing acts by providing its customers with instructions on how to copy the 3DS Header Data is sufficient to meet the first element of the secondary infringement test." 27 The judge said that it could be inferred that the respondent had actual or constructive knowledge of the infringement.

Second, Campbell J. considered the technological protection measures introduced under the Copyright Modernization Act SC 2012 C-42 (Canada). The judge found that all the asserted access control measures were technological protection measures under the Act. Campbell J. found that the respondent was engaged in the circumvention of those technological protection measures: "the evidence plainly shows that the Game Copiers permit users to play unauthorized copies of video games that would otherwise be unplayable without these devices." ${ }^{28}$ The judge also held that the respondent had trafficked in circumvention devices: "the evidence also shows that the Respondent knew that its Game Copiers were used by its customers to play pirated Nintendo Games." ${ }^{29}$ The respondent raised the defence that it was protected by the exception for the "interoperability of computer programs." 30 The judge rejected such arguments: "although homebrew software may be available on the internet and users of the Respondent's devices could theoretically be using them for homebrew, the scale of such activities is dwarfed by the market for illicit and infringing activities." ${ }^{31}$

Third, Campbell J. provided a range of remedies for Nintendo of America Inc., including $\$ 60,000$ in statutory damages in respect of copyright infringement of the Header Data works; $\$ 1,000,000$ in punitive damages; and $\$ 11,700,000$ in statutory damages in respect of circumvention of technological protection measures. There were also orders for pre-judgment interest and post-judgment interest.

Considering the decision, Michael Geist reflected upon the significance of the ruling:

The case is a big win for Nintendo and an exceptionally aggressive application of the new anti-circumvention rules. It leaves no doubt that Canada has one of the most

\footnotetext{
5 Nintendo of America Inc. v Jeramie Douglas King and Go Cyber Shopping (2015) Ltd. 2017 FC 246.

Nintendo of America Inc. v Jeramie Douglas King and Go Cyber Shopping (2015) Ltd. 2017 FC 246 [1].

Nintendo of America Inc. v Jeramie Douglas King and Go Cyber Shopping (2015) Ltd. 2017 FC 246 [58].

Nintendo of America Inc. v Jeramie Douglas King and Go Cyber Shopping (2015) Ltd. 2017 FC 246 [106].

Nintendo of America Inc. v Jeramie Douglas King and Go Cyber Shopping (2015) Ltd. 2017 FC 246 [109].

Nintendo of America Inc. v Jeramie Douglas King and Go Cyber Shopping (2015) Ltd. 2017 FC 246 [113].

31 Nintendo of America Inc. v Jeramie Douglas King and Go Cyber Shopping (2015) Ltd. 2017 FC 246 [121].
} 
restrictive and potentially punitive digital lock rules in the world, with the court adopting expansive interpretations to the digital lock protections and dangerously narrow views of the exceptions (Geist 2017).

However, the ability to engage in law reform in this area would potentially be restricted by prescriptive text like that found in the TPP (Standing Committee on International Trade 2017).

Canadian lawyer Howard Knopf has argued that there is further scope for domestic law reform in respect of technological protection measures (Knopf 2017). He contends that "anti-circumvention measures should be fixed in order to clarify that fair dealing exceptions are 'always available', even where circumvention of TPMs is involved" (Knopf 2017). Moreover, Knopf suggests that "any revision should remove the possibility of criminal liability for non-commercial (e.g., personal) circumvention" (Knopf 2017). There has been a larger concern about the geoblocking of copyright works in Canada (Wagman and Urquhart 2014). This has also been a significant problem in Australia.

\subsection{Australia}

In a mod-chipping case, the High Court of Australia considered the definition of technological protection measures in Australia. ${ }^{32}$ The court stressed:

In these circumstances, it is preferable for this Court to say with some strictness what s 10(1) of the Copyright Act means in its definition of TPM, understood according to the words enacted by the Parliament. If it should transpire that this is different from the purpose that the Parliament was seeking to attain (or if it should appear that later events now make a different balance appropriate) it will be open to the Parliament, subject to the Constitution, to enact provisions clarifying its purpose for the future. ${ }^{33}$

The High Court of Australia expressed concerns that an overly broad reading of technological protection measures could undermine the general regime of copyright law, and its attendant exceptions. Moreover, the judges were concerned about the public policy implications of digital locks for consumer rights, freedom of speech, and competition law. The High Court of Australia was also anxious that an expansive approach to technological protection measures could have significant implications for criminal justice-given the criminal offences associated with technological protection measures.

Despite the cautionary language of the High Court of Australia, the Australian Parliament revised and expanded the regime for technological protection measures in Australia after the introduction of the Australia-United States Free Trade Agreement 2004, with further amendments in 2006.

The Australian Parliamentary inquiry into IT pricing revealed in 2013 that Australian consumers were paying significantly more for IT products and services than their counterparts (House of Representatives Committee on Infrastructure and Communications 2013). Copyright measures such as parallel import restrictions, technological protection measures, geoblocking, and anti-competitive conduct all contributed to this problem. The report recommended a range of initiatives to address the problem of IT pricing in Australia.

The TPP threatened to further prescribe standards in respect of technological protection measures and electronic rights management information. The TPP will also undermine domestic Australian policy initiatives. It will lock nation states into a defective and anachronistic regime for technological protection measures. As Timothy Lee said:

The treaty includes a long section, proposed by the United States, requiring the creation of legal penalties for circumventing copy-protection schemes such as those that prevent copying of DVDs and Kindle books (Lee 2013).

32 Stevens v Kabushiki Kaisha Sony Computer Entertainment [2005] HCA 58.

33 Stevens v Kabushiki Kaisha Sony Computer Entertainment [2005] HCA 58 [223]-[225]. 
Economist Peter Martin lamented that the TPP undermined the Australian inquiry into IT Pricing. "Australia backs the US at every turn against its own consumers" (Martin 2013). Greens Senator Scott Ludlam concurred: "the current TPP text also entrenches the disadvantages Australians experience in being ripped off with unfair IT pricing" (Ludlam 2013).

The TPP will seemingly be beneficial to some of the companies most criticised in the IT pricing inquiry: Adobe, Microsoft, and Apple (Rimmer 2013). It also limits the policy space for governments to craft copyright exceptions. This is disturbing, especially given that the Australian Law Reform Commission (2014), the Harper Review (Harper et al. 2015; Productivity Commission 2016a, 2016b) considered whether Australia should adopt a defence for fair use. James Love of Knowledge Ecology International observed:

One set of technically complex but profoundly important provisions are those that define the overall space that governments have to create exceptions to exclusive rights...In its current form, the TPP space for exceptions is less robust than the space provided in the 2012 WIPO Beijing Treaty or the 2013 WIPO Marrakesh Treaty, and far worse than the TRIPS Agreement (Love 2013). ${ }^{34}$

Maira Sutton and Patrick Higgins of the Electronic Frontier Foundation said that "given the important role that flexibility in copyright has played in enabling innovation and free speech, it's a terrible idea to restrict that flexibility in a trade agreement" (Higgins and Sutton 2013). Only Vietnam sought to put forward positive positions in respect of intellectual property exceptions in the agreement on the topic of fair use, noted Sean Rintel of Electronic Frontiers Australia (Rintel 2013).

The Harper Review discussed copyright law, parallel importation restrictions, technological protection measures, and international price discrimination (Harper et al. 2015).

In its 2016 inquiry into Australia's intellectual property arrangements, the Productivity Commission expressed concerns about the operation of technological protection measures (Productivity Commission 2016a, 2016b). The Productivity Commission was of the view that the scheme was poorly targeted:

While circumvention of a TPM is permitted under the Copyright Act, it is still illegal to supply technologies or services to enable such uses. This leads to the unusual situation where individuals and institutions wishing to legitimately crack a TPM (such as a library wishing to make a preservation copy) will have to create the technologies required to do so themselves (Productivity Commission 2016b, p. 141).

In Recommendation 5.1, the Productivity Commission observed that the Australian Government should amend the Copyright Act 1968 (Cth) to "permit consumers to circumvent technological protection measures for legitimate uses of copyright material." (Productivity Commission 2016b, p. 142)

Professor Kimberlee Weatherall has been particularly critical of the impact of the TPP on copyright law (Weatherall 2016a). She contends: "Chapter 18 is not justifiable for its impact on reducing barriers to trade or promoting economic integration, and even the most ardent supporter of strong IP rights ought to find much to criticise in the prescriptive but incoherent IP standards it seeks to establish" (Weatherall 2016a).

Australia stands to be left in a woeful position. It has been burdened with heavy commitments in respect of copyright protection, without the flexibility of the United States regime, with its defence of fair use and first amendment protection for freedom of speech.

There are also larger concerns about how the TPP would affect Australia's competition policy (Colton 2017).

34 WIPO Beijing Treaty on Audiovisual Performances, signed 24 June 2012; and WIPO Marrakesh Treaty to Facilitate Access to Published Works by Visually Impaired Persons and Persons with Print Disabilities, signed 28 June 2013, and effective 30 September 2016. 


\subsection{New Zealand}

In New Zealand, there has also been disquiet about the operation of technological protection measures and digital locks.

Professor Susy Frankel has reflected upon the genesis of technological protection measures in New Zealand, noting their controversial nature (Frankel 2015). She observed: "When TPMs are protected in their own right, the balance shifts in favour of owners and away from users of copyright works" (Frankel 2015, p. 134). Associate Professor Alexandra Sims (2016) has been concerned about copyright exceptions and limitations being undermined by TPMs, Professor Jane Kelsey has questioned whether the TPP provides for an appropriate regime for electronic commerce and information technology in New Zealand (Kelsey 2010, 2013).

An expert New Zealand report on the TPP highlighted that the agreement would require significant amendments to laws on TPMS (Ting-Edwards et al. 2016). The report noted:

TPPA rules in Article 18.68 go further [than New Zealand's current TPM rules], requiring legal liability for anyone who supplies devices or services for breaking TPMs, or who 'knowingly circumvents' a TPM. The definition of TPM is broad, including a device which controls access to a protected work. Adopting this provision would mean preventing access, and introducing new liability for the act of circumvention. These rules extend to products such as games, streaming media, e-books, and indeed any software or other digital product. There are exceptions, whose interpretation is complicated by somewhat opaque language. The final scope of these provisions would depend on whether, and in what form, New Zealand uses these exceptions to confine liability for breaking TPMs (Ting-Edwards et al. 2016, p. 12).

Digital locks could prove to be a significant barrier in New Zealand in terms of cultural production, access to knowledge, and the innovation economy.

As noted, the Minister of Commerce and Consumer Affairs of the New Zealand Government has called a new copyright review in 2017 (Ministry of Business, Innovation, and Employment, New Zealand Government 2017). The background report noted that there was a debate over the policy settings in terms of the copyright regime:

A review is an opportunity to consider the appropriate balance in the regime. Without the ability to protect works from unauthorised copying/distribution, there would be fewer incentives to create and disseminate important social, cultural and commercial works. However, over-protective copyright settings can inhibit the creation and dissemination of copyright works by restricting competition and trade. Over-protective copyright settings may also impede follow on creation — that is, using existing creative works and the ideas underpinning them to create new works, ideas, products and services (Ministry of Business, Innovation, and Employment, New Zealand Government 2017).

In this context, there is a need to consider the relative impact of technological protection measures in the setting of the economy and culture of New Zealand.

\subsection{Summary}

The introduction of technological protection measures has upset the delicate balances at the heart of copyright law. Niva Elkin-Koren has expressed concerns about the impact of secondary forms of protection upon users' rights:

With the shift from commodity to service the scope of user rights is defined, for the most part, by a license and the design, using Digital Rights Management (DRM) Systems or Technological Protection Measures (TPM). Consequently, users are subject to ongoing and intermittent change in the terms of access to their purchased copies (e.g. Apple reducing 
the number of authorized copies of the playlist) or alternatively their access to purchased content may be terminated altogether (Elkin-Koren 2017).

Given the constitutional challenge against technological protection measures in the United States, it seems unwise to embed the self-same DMCA model in the TPP. There has been considerable debate over the nature and scope of technological protection measures in other jurisdictions such as Canada, Australia, and New Zealand. Such nations should have the regulatory autonomy and freedom to design rules on technological protection measures, to suit their local technological, cultural, and economic conditions. Moreover, states should be able to dispense with technological protection measures altogether, if the regime is not achieving its intended purposes.

\section{Electronic Rights Management Information}

The WIPO Internet Treaties 1996 called for the introduction of both technological protection measures and electronic rights management information. In addition to technological protection measures, the $D M C A$ also introduced Electronic Rights Management Information.

Article 18.69 of the TPP addresses Electronic Rights Management Information (RMI)—sometimes also known as copyright management information. Article 18.69 (1) prescribes the rules in respect of the need for adequate and effective legal remedies to protect electronic rights management information. Moreover, "each Party shall provide for criminal procedures and penalties to be applied if any person is found to have engaged wilfully and for purposes of commercial advantage or financial gain in any of the activities described in subparagraph (a)." Furthermore, "a Party may provide that the criminal procedures and penalties referred to in paragraph 1(b) do not apply to a non-profit library, museum, archive, educational institution or public non-commercial broadcasting entity."

Article 18.69 (2) of the TPP provides: "For greater certainty, nothing prevents a Party from excluding from a measure that implements paragraph 1 a lawfully authorised activity that is carried out for the purpose of law enforcement, essential security interests or other related governmental purposes, such as the performance of a statutory function."

Article 18.69 (3) of the TPP suggests: "for greater certainty, nothing in this Article shall obligate a Party to require a right holder in a work, performance or phonogram to attach RMI to copies of the work, performance or phonogram, or to cause RMI to appear in connection with a communication of the work, performance or phonogram to the public."

Article 18.69 (4) of the TPP provides a broad definition of rights management information: "RMI means: (a) information that identifies a work, performance or phonogram, the author of the work, the performer of the performance or the producer of the phonogram; or the owner of any right in the work, performance or phonogram; (b) information about the terms and conditions of the use of the work, performance or phonogram; or (c) any numbers or codes that represent the information referred to in subparagraphs (a) and (b), if any of these items is attached to a copy of the work, performance or phonogram or appears in connection with the communication or making available of a work, performance or phonogram to the public."

The model for this regime seems to be the DMCA. There has been a ruling that the provision covers non-digital attribution. ${ }^{35}$ There has been legal debate as to whether copyright management information applies to works in non-digital form. ${ }^{36}$

35 Murphy v. Millennium Radio Group, LLC, 650 F.3d 295 (3rd Cir. 2011).

36 Textile Secrets International, Inc. v. Yay-Ya Brand Inc., 24 F. Supp.2d 1184 (C.D. Cal. 2007); IQ Group, Ltd. v. Wiesner Publishing, LLC, 409 F.Supp.2d 587 (D.N.J.2006); McClatchey v. The Associated Press, 2007 WL 776103 (W.D.Pa. March 9, 2007); and Fox v. Hildebrand, 2009 WL 1977996 (C.D. Cal. 1 July 1 2009). 


\section{Conclusions}

Far from promoting a free and open Internet, the TPP has instead promulgated a heavy-handed vision of copyright crime and punishment. Such a punitive regime seems to run against the hopes of Obama that the TPP would promote Internet freedom, electronic commerce, and digital trade. Indeed, as Nobel Laureate Joseph Stiglitz has warned, the TPP may further widen the digital divide, and exacerbate social inequalities, both within developed countries and developing countries, as well as between those nations. The TPP sought to entrench the DMCA in legal systems across the Pacific Rim-even though that very regime is under review and question in the United States. The TPP hoped to lay down rules on intermediary liability across the Pacific Rim. The TPP entrenches the dubious regime for technological protection measures set down in the DMCA. Moreover, there are also extensive provisions on electronic rights management information. Moreover, the TPP contains a battery of provisions on copyright enforcement-looking at civil remedies, criminal offences, and border measures (Weatherall 2016b). ${ }^{37}$ This regime seeks to dictate a copyright maximalist regime across the Pacific Rim. As Peter Drahos (2016) notes, "some provisions travel much more deeply into domestic sovereign space than the original corporate architects of TRIPS could ever have imagined."

Importantly, the Intellectual Property Chapter of the TPP is reinforced by the Electronic Commerce Chapter (Kilic and Israel 2015). There has also been debate about the regime for telecommunications in the TPP (Kotlowitz and Voon 2016). For their part, multinational information technology companies were attracted to the Electronic Commerce chapter of the TPP. A number of major companies-represented by the Computer and Communications Industry Association, the Internet Association, and the Consumer Electronics Association-welcomed the TPP because it would result in the harmonisation of rules on trade in data (Computer and Communications Industry Association 2015; Internet Association 2016; Consumer Electronics Association 2015). However, civil society groups such as Public Citizen and the Canadian Internet Policy and Public Interest Clinic were concerned about the impact of the Electronic Commerce chapter of the TPP upon consumer rights (Kilic and Israel 2015). Furthermore, there was criticism that the regime in the TPP did little to protect the privacy rights of individuals and citizens in the Pacific Rim. There has been disquiet about the impact of the TPP upon network neutrality. There was also a concern about whether the TPP was hostile to open source software. The Electronic Commerce chapter raises a whole host of questions about the role of trade in the internet ecosystem under the TPP (Mishra 2017). In addition to the TPP, similar measures on electronic commerce have been promulgated in the Trade in Services Agreement (TISA) (Australia Government Department of Foreign Affairs and Trade 2015b), and the Trans-Atlantic Trade and Investment Agreement (TTIP) (Australia Government Department of Foreign Affairs and Trade 2015b; European Commission n.d.) The topic of rewriting electronic commerce rules through trade agreements such as the TPP, TISA, and TTIP is a vast field. The Obama initiatives on electronic commerce are also a highly uncertain area given Trump's disavowal of the TPP, and non-committal position towards TISA and TTIP (Trans-Atlantic Trade and Investment Agreement (TTIP). This important but sweeping topic is certainly deserving of further consideration and investigation elsewhere.

The greatest controversy has been regarding the Investment Chapter in the TPP. Providing copyright owners with a super-remedy of Investor-State Dispute Settlement is a startling, radical new power. Disturbingly, the investment chapter in the TPP defines investment broadly-including intellectual property rights. The treaty transforms intellectual property rights from privileges designed to promote the 'progress of science and the useful arts' into instrumental tools for foreign investment. This means companies could challenge, frustrate, and even block intellectual property reforms under the investment chapter of the TPP. The linkage between intellectual property and investment also raises issues in respect of copyright law, IT pricing, and the Digital Economy. The investment chapter may frustrate any efforts by parliaments in the Pacific Rim to engage in progressive reform in respect

37 Professor Weatherall argues that such regimes need greater safeguards. 
of intellectual property. An investor-state dispute resolution mechanism could be deployed by foreign investors to challenge intellectual property reforms.

Corynne McSherry and Maira Sutton from the Electronic Frontier Foundation have considered the impact of investor state dispute settlement upon copyright law reform under the TPP and the Trans-Atlantic Trade and Investment Partnership (McSherry and Sutton 2013). The writers observed that Big Content companies could use investment clauses to undermine copyright law reform and other digital regulation:

Let's say a country adopts a new flexible copyright law ... Companies could bring an investor-state case, alleging that the policy undermines their copyright protections, and therefore, their profits. Or, more likely, it could use the threat of such a lawsuit to stop that law from getting passed in the first place. Indeed, given the perverse nature of investor-state powers, even if all the other harmful provisions are taken out of the TPP, corporations could still have the ability to attack and potentially unravel virtually any pro-user digital regulation (McSherry and Sutton 2013).

McSherry and Sutton (2013) noted: "The investor-state provision is just one of many problems in the TPP." The Electronic Frontier Foundation attorneys said: "at the root of all of this, however, is that the secret trade negotiation process is a vehicle for multinational corporations to lobby for provisions that will impact how users interact, share, and develop technological tools and content-without any opportunity for those users to know about, much less comment on, those provisions." The tobacco industry has, unsuccessfully, used investor clauses to question Uruguay's graphic health warnings, and Australia's regime for the plain packaging of tobacco products (Crosbie et al. 2017; Barlow 2015; Hepburn and Peterson 2015). ${ }^{38}$ Eli Lilly has challenged Canada's patent laws under an investment clause in NAFTA, but lost in the action (Gold 2007). ${ }^{39}$ Copyright reforms could similarly be challenged by copyright industries under an investment clause in the TPP (Technology Companies 2014). There will no doubt be future debate and discussion over the interaction between intellectual property and Investor-State Dispute Settlement (Yu 2017a). Professor Gus van Harten wonders whether it is time to redesign or terminate Investor-State Arbitration (Van Harten 2017).

The fate of the TPP remains in doubt, with departure of the United States negotiations. Australia has been encouraging other nations that the TPP can continue, with 11 members, in the absence of the United States (Seno 2017). While new United States President Donald Trump has disavowed the TPP, many of the proposals about intellectual property, investment, and electronic commerce in the TPP seem to be resurrected in current discussions over the renegotiation of NAFTA (Malcolm 2017). The new President has called for a re-evaluation of United States trade agreements to determine whether they are indeed beneficial (Greenwood 2017). For their part, the remaining 11 countries have been considering options for the renegotiation and reformulation of the TPP, without the inclusion of the United States. In particular, Australia, New Zealand, and Japan have been leading the charge for TPP-11 (Agence France-Presse 2017). There has also been much discussion of another regional trade agreement in the Asia-Pacific, the Regional Comprehensive Economic Partnership (RCEP) (Australia Government Department of Foreign Affairs and Trade 2016b). A number of participants in that agreement—such as Japan—have mooted TPP style standards (Malcolm 2016; Yu 2017b).

Nation states excluded from the scope of the TPP have voiced their concern about the impact of mega-regional agreements upon flexibilities in respect of intellectual property-including those relating to copyright law, education, and development. In 2017, the delegations of Brazil, China, India, South Africa, and Fiji tabled a paper to the WTO's TRIPS Council entitled 'Intellectual Property and the Public Interest' (Knowledge Ecology International 2017). The paper complained that "a slew of regional trade agreements containing 'TRIPS plus' standards of IP protection and enforcement have the potential

38 Philip Morris v. Uruguay and Philip Morris v. The Commonwealth of Australia.

39 Eli Lilly and Company v. Government of Canada. 
to significantly affect the policy space available for effective and full use of the TRIPS flexibilities" (Knowledge Ecology International 2017). The delegations highlighted how increased "copyright protections create similar problems of access to knowledge goods, limiting the ability of many people around the world to access print, audio, or visual works of education or entertainment that we take for granted" (Knowledge Ecology International 2017). Moreover, the delegations maintained: "Investor-State disputes under regional or bilateral investment protection agreements are also emerging as significant threats to the use of TRIPS flexibilities in the public interest" (Knowledge Ecology International 2017). There remains much debate about China's responses to the TPP (Drahos 2016).

Whatever the fate of the TPP, there is a need to ensure that our future copyright laws are flexible, agile, responsive, and adaptable - and not locked in by trade agreements to the anachronistic standards of the DMCA. As Joseph Stiglitz and his collaborators have commented, 'Copyright must be calibrated so as to remove unjust barriers to access, and to ensure that the most vulnerable among us can access the vast opportunities that a high-quality education provides' (Baker et al. 2017, p. 57).

Conflicts of Interest: The author declares no conflict of interest.

\section{Appendix A. Case Law}

The Authors Guild v. Google, Inc., 770 F. Supp. 2d 666 (S.D.N.Y. 2011).

The Authors Guild v. Google, Inc., 282 F.R.D. 384 (S.D.N.Y. 2012).

The Authors Guild v. Google, Inc., 721 F.3d 132, 134 (2d Cir. 2013).

The Authors Guild, Inc. v. Google Inc., 954 F.Supp.2d 282 (S.D.N.Y. 2013).

The Authors Guild v. Google Inc. 804 F. 3d 202 (2015) United States Court of Appeals, Second Circuit.

The Authors Guild v. Google Inc., (2016) No. 15-849, http:/ / www.scotusblog.com/case-files/cases/ authors-guild-v-google-inc/

Chamberlain Group, Inc. v. Skylink Technologies, Inc., 381 F.3d 1178 (Fed. Cir. 2004).

Dallas Buyers Club LLC v iiNet Limited [2015] FCA 317.

Eldred v. Ashcroft 537 U.S. 186 (2003).

Fox v. Hildebrand 2009 WL 1977996 (C.D. Cal. 1 July 2009).

Complaint for Declaratory and Injunctive Relief in Green, Huang and Alphamax LLC v Lynch, Hayden, and Pallante (2016) https: / /www.eff.org/document/1201-complaint and https:/ / www.eff.org/ files / 2016/07/21/1201_complaint.pdf

IQ Group, Ltd. v. Wiesner Publishing, LLC, 409 F.Supp.2d 587 (D.N.J. 2006).

Lenz v. Universal Music Corporation 2015 WL 5315388 (C.A.9 (Cal.)).

Lenz v. Universal Music Corporation—Petition for certiorari denied 19 June 2017 http: / / www.scotusblog. $\mathrm{com} /$ case-files/cases/lenz-v-universal-music-corp/

Lexmark International, Inc. v. Static Control Components, 387 F.3d 522 (6th Cir. 2005).

McClatchey v. The Associated Press, 2007 WL 776103 (W.D.Pa. 9 March 2007).

Murphy v. Millennium Radio Group, LLC, 650 F.3d 295 (3rd Cir. 2011).

Nintendo of America Inc. v Jeramie Douglas King and Go Cyber Shopping (2015) Ltd 2017 FC 246.

Recording Industry Association NZ Inc. v. Telecom NZ 3553 [2013] NZCopyT 6 (16 April 2013).

Recording Industry Association New Zealand v. Telecom NZ 4296 [2013] NZCopyT 10; [2013] NZCOP 10 (16 July 2013).

Roadshow Films Pty Ltd v. iiNet Ltd [2012] HCA 16 (20 April 2012).

Roadshow Films Pty Ltd v. Telstra Corporation Ltd [2016] FCA 1503 (15 December 2016).

Stevens v. Kabushiki Kaisha Sony Computer Entertainment [2005] HCA 58.

Storage Technology Corporation v. Custom Hardware Engineering \& Consulting, Inc., 421 F.3d 1307 (Fed. Cir. 2005).

Textile Secrets International, Inc. v. Yay-Ya Brand Inc., 24 F. Supp.2d 1184 (C.D. Cal. 2007).

Tracfone Wireless, Inc. v. Anadisk LLC, 685 F. Supp.2d 1304 (S.D. Fla. 2010). 
Twentieth Century Fox Film Corporation v. Dotcom [2015] NZHC 3349 http:/ / www.nzlii.org/cgi-bin/ sinodisp/nz/cases/NZHC/2015/3349.html.

Universal Music Australia Pty Limited v. TPG Internet Pty Ltd [2017] FCA 435.

Viacom International Inc. and others v. YouTube, Inc. 718 F. Supp. 2d 514 (2010).

Viacom International Inc. and others v. YouTube, Inc. 940 F. Supp. 2d 110 (2013).

Voltage Pictures, LLC v. John Doe, 2017 FCA 97 (CanLII).

\section{Appendix B. Legislation}

Copyright Act 1968 (Cth).

Copyright Act 1994 (NZ).

Copyright Amendment (Disability and Other Access Measures) Bill 2016 (Cth).

Copyright Amendment (Disability and Other Access Measures) Act 2017 (Cth).

Copyright Amendment (Online Infringement) Act 2015 (Cth).

Copyright Amendment (Online Infringement) Act 2015 (Cth), Parliamentary Debate, Committee Report, and Submissions http:/ / www.aph.gov.au/Parliamentary_Business/Bills_Legislation/Bills_Search_ Results / Result?bId=r5446.

Copyright (Infringing File Sharing) Amendment Act 2011 (NZ).

Copyright Modernization Act 2012 C-42 (Canada).

Digital Millennium Copyright Act 1998 (US).

Stop Online Piracy Act HR 3261 (US).

\section{Appendix C. International Treaties}

Anti-Counterfeiting Trade Agreement 2011, [2011] ATNIF 22, not yet in force.

Australia-United States Free Trade Agreement (AUSFTA), signed 18 May 2004 (entered into force 1 January 2005).

North American Free Trade Agreement (NAFTA) 199332 ILM 289, 605 (1993).

Regional Comprehensive Economic Partnership, http://dfat.gov.au/trade/agreements/rcep/Pages/ regional-comprehensive-economic-partnership.aspx.

Trade in Services Agreement (TISA) http:/ / dfat.gov.au/trade/agreements/trade-in-services-agreement/ pages/trade-in-services-agreement.aspx.

Trans-Atlantic Trade and Investment Agreement (TTIP) http:/ /ec.europa.eu/trade/policy/in-focus/ttip/. Trans-Pacific Partnership 2015 (TPP) http:/ / dfat.gov.au/trade/agreements/tpp/official-documents/ Pages/official-documents.aspx.

TRIPS Agreement 19941869 UNTS 299; 33 ILM 1197 (1994).

WIPO Beijing Treaty on Audiovisual Performances, signed 24 June 2012.

WIPO Copyright Treaty 1996 S. Treaty Doc. No. 105-17 (1997); 36 ILM 65(1997).

WIPO Marrakesh Treaty to Facilitate Access to Published Works by Visually Impaired Persons and Persons with Print Disabilities, signed 28 June 2013, and effective 30 September 2016.

WIPO Performances and Phonograms Treaty 1996 S. Treaty Doc. No. 105-17, 36 ILM 76 (1997).

\section{Appendix D. International Disputes}

Eli Lilly and Company v. Government of Canada http:/ / www.international.gc.ca/trade-agreementsaccords-commerciaux/topics-domaines/disp-diff/eli.aspx?lang=eng.

Philip Morris v. The Commonwealth of Australia, http://www.italaw.com/cases/851.

Philip Morris v. Uruguay http://www.italaw.com/cases/460. 


\section{References}

Agence France-Presse. 2017. Australia Leads Fight to Save Trans-Pacific Partnership Trade Pact. The Guardian. Available online: https:/ /www.theguardian.com/business/2017/may/21/australia-leads-fight-to-savetrans-pacific-partnership-trade-pact?CMP=share_btn_tw (accessed on 1 July 2017).

Australia Government Department of Foreign Affairs and Trade. 2015a. Trans-Pacific Partnership (TPP). Available online: http://dfat.gov.au/trade/agreements/tpp/official-documents/Pages/official-documents.aspx (accessed on 26 July 2017).

Australia Government Department of Foreign Affairs and Trade. 2015b. Trade in Services Agreement (TISA). Available online: http:/ / dfat.gov.au/trade/agreements/trade-in-services-agreement/pages/tradein-services-agreement.aspx (accessed on 26 July 2017).

Australian Government. 2016. National Interest Analysis of the Trans-Pacific Partnership Agreement. Available online: http: / / www.aph.gov.au/ /media/02\%20Parliamentary $\% 20$ Business /24\%20Committees / $244 \%$ 20Joint\%20Committees/JSCT/2016/9Feb2016/NIA/TPP\%20National\%20Interest\%20Analysis.pdf (accessed on 1 July 2017).

Australia Government Department of Foreign Affairs and Trade. 2016. Regional Comprehensive Economic Partnership. Available online: http:/ / dfat.gov.au/trade/agreements/rcep/Pages/regional-comprehensiveeconomic-partnership.aspx (accessed on 26 July 2017).

Australian Law Reform Commission. 2014. Copyright and the Digital Economy (ALRC Report 122); Sydney: The Australian Law Reform Commission. Available online: http:/ / www.alrc.gov.au/publications / copyrightreport-122 (accessed on 1 July 2017).

Senate Foreign Affairs, Defence, and Trade References Committee. 2017. Proposed Trans-Pacific Partnership; Canberra: Australian Parliament. Available online: http://www.aph.gov.au/Parliamentary_Business/ Committees/Senate/Foreign_Affairs_Defence_and_Trade/TPP/Report (accessed on 1 July 2017).

Baker, Dean, Jayadev Arjun, and Joseph Stiglitz. 2017. Innovation, Intellectual Property, and Development: A Better Set of Approaches for the 21st Century, AccessIBSA. Available online: http:/ /ip-unit.org/wp-content/ uploads / 2017/07/IP-for-21st-Century-EN.pdf (accessed on 1 July 2017).

Barlow, Karen. 2015. Trade Pact Tested, Australia Wins Big Tobacco Fight. The Huffington Post. Available online: http:/ / www.huffingtonpost.com.au/2015/12/17/australia-plain-packaging-big-tobacco_ n_8834270.html?utm_hp_ref=australia (accessed on 18 December 2015).

Black, Edward. 2011. Internet Users, Free Speech Experts, Petition against SOPA. The Huffington Post. Available online: http:/ / www.huffingtonpost.com/edward-j-black/stop-online-piracy-act-vote_b_1145949.html (accessed on 13 December 2011).

Brennan, Anissa. 2016. The TPP will Foster Digital Trade and Grow Our Economy. Motion Picture Association of America. Available online: http:/ / www.mpaa.org/the-tpp-will-foster-digital-trade-grow-our-economy/ (accessed on 18 February 2016).

Bridy, Annemarie. 2015. A User-Focused Commentary on the Trans-Pacific Partnership ISP Safe Harbors. InfoJustice, November 23. Available online: http:/ / infojustice.org/archives/35402 (accessed on 1 July 2017).

Bridy, Annemarie, and Daphne Keller. 2016. U.S. Copyright Office Section 512 Study: Comments in Response to Notice of Inquiry. Available online: https:/ / ssrn.com/abstract=2757197 (accessed on 31 March 2016).

Burgess, Joel. 2015. The Consequences for Not Buying the Dallas Buyers Club. TechRadar. April 9. Available online: http:/ / www.techradar.com/au/news/internet/policies-protocols/the-consequencesfor-not-buying-the-dallas-buyers-club-1290593 (accessed on 1 July 2017).

Carrier, Michael. 2013. SOPA, PIPA, ACTA, TPP: An Alphabet Soup of Innovation-Stifling Copyright Legislation and Agreements. Northwestern Journal of Technology and Intellectual Property 11: 21-31. Available online: http:/ / ssrn.com/abstract=2213034 (accessed on 1 July 2017).

Colton, Caroline. 2017. Contestability "Theory", Its Links with Australia's Competition Policy, and Recent International Trade and Investment Agreements. Australian Journal of International Affairs 71: 315-34. [CrossRef]

Computer and Communications Industry Association. 2015. Trans-Pacific Partnership. Available online: http: / / www.ccianet.org/issues/trade/trans-pacific-partnership/ (accessed on 1 July 2017). 
Consumer Electronics Association. 2015. CEA Applauds U.S., 11 Other Nations for Trans-Pacific Partnership Deal. Press Release. October 5. Available online: https: / www.cta.tech/News/Press-Releases / 2015/October/ CEA-Applauds-U-S-,-11-Other-Nations-for-Trans-Paci.aspx (accessed on 1 July 2017).

Coyne, Allie. 2015. Village Roadshow Boosts Donations Amidst Copyright Crackdown. IT News, February 2. Available online: http:/ / www.itnews.com.au/news/village-roadshow-boosts-donations-amidst-copyrightcrackdown-399933 (accessed on 1 July 2017).

Craig, Carys. 2011. Copyright, Communication and Culture: Towards a Relational Theory of Copyright Law. Cheltenham: Edward Elgar.

Craig, Carys. 2017. Technological Neutrality: Recalibrating Copyright in the Information Age. Theoretical Issues in Law 13: 601-32.

Crosbie, Eric, Patricia Sosa, and Stanton Glantz. 2017. Defending Strong Tobacco Packaging and Labelling Regulations in Uruguay: Transnational Tobacco Control Network versus Philip Morris International. Tobacco Control. March 23. Available online: http://tobaccocontrol.bmj.com/content/early/2017/03/ 22/tobaccocontrol-2017-053690 (accessed on 1 July 2017).

Crozier, Ry. 2015. Dallas Buyers Club Pirates Could be Told to Name a Price. IT News. April 13. Available online: http: / www.itnews.com.au/News / 402624,dallas-buyers-club-pirates-could-be-told-to-name-aprice.aspx (accessed on 1 July 2017).

The Hon. Clare Curran. 2011. The Copyright (Infringing File Sharing) Amendment Bill. Wellington: New Zealand Parliament, Available online: https://www.parliament.nz/en/pb/hansard-debates/rhr/document/ 49HansD_20110413_00001942/copyright-infringing-file-sharing-amendment-bill-second (accessed on 1 July 2017).

Deere, John. 2015. Long Comment Regarding a Proposed Exemption Under 17 U.S.C. 1201. United States Copyright Office. Available online: http:/ / copyright.gov/1201/2015/comments-032715/class\%2021/John_ Deere_Class21_1201_2014.pdf (accessed on 1 July 2017).

Doctorow, Cory. 2015a. A Roadmap for Killing TPP: The Next SOPA Uprising. Boing Boing, December 1. Available online: http:/ / boingboing.net/2015/12/01/a-roadmap-for-killing-tpp-the.html (accessed on 1 July 2017).

Doctorow, Cory. 2015b. Some Countries Learned from America's Copyright Mistakes: TPP Will Undo That. Boing Boing, December 17. Available online: http:/ / boingboing.net/2015/12/17/some-countries-learned-fromam.html (accessed on 1 July 2017).

Doctorow, Cory. 2016a. Landmark Study on the Effects of Copyright Takedown Abuse on Online Free Expression. Boing Boing, March 30. Available online: http://boingboing.net/2016/03/30/landmark-study-on-theeffects.html (accessed on 1 July 2017).

Doctorow, Cory. 2016b. America's Broken Digital Copyright Law is about to be challenged in Court. Boing Boing, July 21. Available online: https:/ /www.theguardian.com/technology/2016/jul/21/digital-millenniumcopyright-act-eff-supreme-court?CMP=share_btn_tw (accessed on 1 July 2017).

Doctorow, Cory. 2017a. An Open Letter on DRM to the Inventor of the Web from the Inventor of Net Neutrality. Boing Boing, April 28. Available online: http:/ / boingboing.net/2017/04/28/two-tims.html (accessed on 1 July 2017).

Doctorow, Cory. 2017b. What's Wrong with the Copyright Office's DRM Study? Boing Boing, June 29. Available online: http:/ / boingboing.net/2017/06/29/absolutely-nothing-say-it-agai.html (accessed on 1 July 2017).

Drahos, Peter. 2001. BITs and BIPs: Bilateralism in Intellectual Property. Journal of World Intellectual Property 4 : 791-808. [CrossRef]

Drahos, Peter. 2016. China, the TPP and Intellectual Property. IIC-International Review of Intellectual Property and Competition Law 47: 1-4. [CrossRef]

Dreams, Common. 2014. New Campaign Launched: “10 Days to Stop Fast Track" Brings Together Diverse Network of Labor, Internet, and Environmental Activists. Common Dreams, January 23. Available online: http:/ / www.commondreams.org/newswire/2014/01/23/new-campaign-launched-10-days-stopfast-track-brings-together-diverse-network (accessed on 1 July 2017).

Duhamel, Francois, and Raul Bringas. 2016. Impact of Trans-Pacific Partnership's Intellectual Property Rights Issues for Mexico and China. In China and Latin America in Transition. Edited by Shoujun Gui and Manuel Perez Garca. New York: Palgrave Macmillan, pp. 189-204. 
Electronic Frontier Foundation. 2015. Cory Doctorow Rejoins EFF to Eradicate DRM Everywhere. Press Release. Available online: https:/ /www.eff.org/press/releases/cory-doctorow-rejoins-eff-eradicate-drmeverywhere (accessed on 1 July 2017).

Electronic Frontier Foundation. 2016. Complaint for Declaratory and Injunctive Relief in Green, Huang and Alphamax LLC v Lynch, Hayden, and Pallente. Available online: https://www.eff.org/files/2016/07/21/ 1201_complaint.pdf (accessed on 1 July 2017).

Elkin-Koren, Niva. 2017. Copyright in a Digital Ecosystem: A User Rights Approach. In Copyright Law in an Age of Limitations and Exceptions. Edited by Ruth Okediji. Cambridge: Cambridge University Press, pp. 132-68.

Ernesto. 2016. Accused “Pirate” Questions Dallas Buyers Club's Copyright Claim. Torrentfreak, July 18. Available online: https: / / torrentfreak.com/accused-pirate-questions-dallas-buyers-clubs-copyright-claim-160718/ (accessed on 1 July 2017).

European Commission. n.d. Trans-Atlantic Trade and Investment Agreement (TTIP). Available online: http: / / ec.europa.eu/trade/policy/in-focus/ttip/ (accessed on 1 July 2017).

Fifield, Mitch. 2017. Improving Access to Copyright Material. Australian Government, The Department of Communications and the Arts, March 22. Available online: http:/ / www.minister.communications.gov.au/ mitch_fifield/news/improving_access_to_copyright_material\#.WNw6xVdMGHe (accessed on 1 July 2017).

Finley, Klint. 2016. The Inventors of the Internet Are Trying to Build a Truly Permanent Web. Wired. June 20. Available online: http:/ / www.wired.com/2016/06/inventors-internet-trying-build-truly-permanent-web/ (accessed on 1 July 2017).

Fisher, David. 2013. The Secret Life of Kim Dotcom: Spies, Lies and the War for the Internet. Auckland: David Fisher Books.

Ford, George S. 2017. Notice and Takedown in Everyday Practice: A Review. Available online: https:/ / papers. ssrn.com/sol3 / papers.cfm?abstract_id=2963230 (accessed on 1 July 2017).

Francis, Hannah. 2016. Three Strikes' Scheme for Aussie Pirates Scrapped: Report. The Sydney Morning Herald, February 18. Available online: http://www.smh.com.au/technology/technology-news/three-strikesscheme-for-aussie-pirates-scrapped-report-20160218-gmxie1.html (accessed on 1 July 2017).

Frankel, Susy. 2015. Test Tubes for Global Intellectual Property Issues: Small Market Economies. Cambridge: Cambridge University Press.

Fulton, Sandra. 2012. The Biggest Threat to Free Speech and Intellectual Property That You've Never Heard of. American Civil Liberties Union. Available online: https:/ / www.aclu.org/blog/biggest-threat-free-speechand-intellectual-property-youve-never-heard (accessed on 29 April 2012).

Gardner, Eriq. 2017. Supreme Court Turns Down "Dancing Baby" Copyright Case. Hollywood Reporter. June 19. Available online: http:/ / www.hollywoodreporter.com/thr-esq/supreme-court-turns-down-dancing-babycopyright-case-1014641 (accessed on 1 July 2017).

Gaylor, Brett. 2015. Canadian Filmmaker Fears for Creative Freedom under the TPP. Electronic Frontier Foundation, August 6. Available online: https://www.eff.org/deeplinks/2015/08/tpp-leaks-reveal-blows-creativefreedom-says-filmmaker (accessed on 1 July 2017).

Geist, Michael. 2016a. The Trouble with the TPP: Damages for Breaking Digital Locks for Personal Purposes. Available online: http:/ / www.michaelgeist.ca/2016/02/the-trouble-with-the-tpp-day-37-damages-forbreaking-digital-locks-for-personal-purposes / (accessed on 24 February 2016).

Geist, Michael. 2016b. How a File-Sharing Lawsuit against Rogers threatens your Internet Privacy. Available online: https:/ /www.thestar.com/business/2016/06/27/how-a-file-sharing-lawsuit-againstrogers-threatens-your-internet-privacy-geist.html (accessed on 27 June 2016).

Geist, Michael. 2016c. The Trouble with the TPP's Copyright Rules. In The Trans-Pacific Partnership and Canada: A Citizen's Guide. Edited by Scott Sinclair and Stuart Trew. Toronto: James Lorimer \& Company Ltd., pp. 158-68.

Geist, Michael. 2017. Canadian DMCA in Action: Court Awards Massive Damages in First Major Anti-Circumvention Copyright Ruling. March 3. Available online: http://www.michaelgeist.ca/2017/ 03/canadian-dmca-in-action-court-issues-massive-damage-award-in-first-major-anti-circumventioncopyright-ruling/ (accessed on 1 July 2017).

Gillespie, Tarleton. 2017. Wired Shut: Copyright and the Shape of Digital Culture. Cambridge and London: The MIT Press. 
Gold, Richard. 2007. NAFTA Patent Ruling a Big Victory for Canadian Innovation. Globe and Mail, April 6. Available online: http:/ / www.theglobeandmail.com/report-on-business/rob-commentary/nafta-patentruling-a-big-victory-for-canadian-innovation/article34617647/ (accessed on 1 July 2017).

Greenwood, Max. 2017. Trump Signs Order Calling for Review of Trade Deals. The Hill, April 29. Available online: http:/ / thehill.com/homenews/administration/331247-trump-signs-order-calling-for-review-oftrade-deals?rnd=1493508374 (accessed on 1 July 2017).

Grubb, Ben, and Michaela Whitbourn. 2015. Pirates Beware: Hollywood is coming after You. The Sydney Morning Herald, April 8. Available online: http:/ / www.smh.com.au/digital-life/digital-life-news/pirates-bewarehollywood-is-coming-after-you-20150407--1mg2ui.html (accessed on 1 July 2017).

Haggart, Blayne. 2014. Copyfight: The Global Politics of Digital Copyright Reform. Toronto: The University of Toronto Press.

Harper, Ian, Peter Anderson, Sue McCluskey, and Michael O’Bryan. 2015. Competition Policy Review: Final Report; Canberra: The Australian Government. Available online: http:/ /competitionpolicyreview.gov.au/files/ 2015/03/Competition-policy-review-report_online.pdf (accessed on 1 July 2017).

Hepburn, Jarrod, and Luke Eric Peterson. 2015. Australia Prevails in Arbitration with Philip Morris Over Tobacco Plain Packaging Dispute. Investment Arbitration Reporter, December 17. Available online: https:/ / www.iareporter.com/articles/breaking-australia-prevails-in-arbitration-withphilip-morris-over-tobacco-plain-packaging-dispute/ (accessed on 1 July 2017).

Higgins, Parker. 2013. Hackers, Makers, and Tinkerers: Here's How TPP Would Hurt You. Electronic Frontier Foundation, May 10. Available online: https://www.eff.org/deeplinks/2013/05/hackers-makers-andtinkerers-heres-how-tpp-would-hurt-you (accessed on 1 July 2017).

Higgins, Parker. 2016. Research and Remixes the Law Won't Allow. Electronic Frontier Foundation, July 21. Available online: https:/ / www.eff.org/deeplinks/2016/07/research-and-remixes-law-wont-allow (accessed on 1 July 2017).

Higgins, Parker, and Maira Sutton. 2013. TPP Leak Confirms the Worst: US Negotiators Still Trying to Trade Away Internet Freedoms. Electronic Frontier Foundation, November 13. Available online: https://www.eff.org/deeplinks/2013/11/tpp-leak-confirms-worst-us-negotiators-still-tryingtrade-away-internet-freedoms (accessed on 1 July 2017).

Horten, Monica. 2013. A Copyright Masquerade: How Corporate Lobbying Threatens Online Freedoms. London and New York: Zed Books.

House of Representatives Committee on Infrastructure and Communications. 2013. At What Cost? IT Pricing and the Australia Tax; Canberra: Australian Parliament, July 29. Available online: http://www.aph.gov.au/ parliamentary_business/committees/house_of_representatives_committees?url=ic/itpricing/report.htm (accessed on 1 July 2017).

Huang, Andrew. 2016. Why I'm Suing the US Government. Bunnie: Studios. July 21. Available online: https: / / www.bunniestudios.com/blog/?p=4782 (accessed on 1 July 2017).

Hughes, Gareth. 2011. Copyright (Infringing File Sharing) Amendment Bill—Second Reading, In Committee, Third Reading. Available online: https:/ / www.parliament.nz/en/pb/hansard-debates/rhr/document/ 49HansD_20110413_00001942/copyright-infringing-file-sharing-amendment-bill-second (accessed on 1 July 2017).

Hunter, Dan. 2014. Blocking Piracy Websites is Bad for Australia's Digital Future. SBS, November 25. Available online: http://www.sbs.com.au/news/article/2014/11/25/blocking-piracy-websites-badaustralias-digital-future (accessed on 1 July 2017).

Hunter, Dan, and Nicolas Suzor. 2015. Claiming the Moral High Ground in the Copyright Wars. In Copyfight: Firing Up Conversation about Copyright. Edited by Phillipa McGuinness. Sydney: University of New South Wales Press.

Husic, Ed. 2017. Second Reading Speech on the Copyright Amendment (Disability Access and Other Measures) Bill 2017 (Cth). Hansard, the House of Representatives, the Australian Parliament, March 28, p. 66. Available online: http:/ / parlinfo.aph.gov.au/parlInfo/search/display/display.w3p;query=Id\%3A\%22chamber\% 2Fhansardr\%2Fdde32dd1--36a6--430d-9e08--0e0de7b6aecd\%2F0156\%22 (accessed on 1 July 2017).

Internet Association. 2016. Statement in Support of the Trans-Pacific Partnership. Press Release. March 30. Available online: https:/ /internetassociation.org/033016tpp/ (accessed on 31 July 2017). 
Kaminski, Margot. 2014. The Capture of International Intellectual Property Law through the U.S. Trade Regime. Southern California Law Review 87: 977-1052.

Jane Kelsey, ed. 2010. No Ordinary Deal: Unmasking the Trans-Pacific Partnership Free Trade Agreement. Wellington: Bridget Williams Books Inc.

Kelsey, Jane. 2013. Hidden Agendas: What We Need to Know about the Trans-Pacific Partnership Agreement (TPPA). Wellington: Bridget Williams Books Limited.

Kilic, Burcu, and Tamir Israel. 2015. The Highlights of the Trans-Pacific Partnership E-Commerce Chapter. Public Citizen and the Samuelson-Gushko Canadian Internet Policy and Public Interest Clinic, November 5. Available online: http:/ / www.citizen.org/documents/tpp-ecommerce-chapter-analysis.pdf (accessed on 1 July 2017).

Knowledge Ecology International. 2017. WTO TRIPS Council: Brazil, China, Fiji, India, and South Africa Table Agenda Item On IP and the Public Interest. Available online: http:/ / keionline.org/node/2800 (accessed on 6 June 2017).

Knopf, Howard. 2017. Once more into the Copyright Breach. Policy Options_Politiques, June 19. Available online: http:/ / policyoptions.irpp.org/magazines/june-2017/once-more-into-the-copyright-breach/ (accessed on 1 July 2017).

Kotlowitz, Danny, and Tania Voon. 2016. Telecommunications Services in the Trans-Pacific Partnership: Will the Mobile Roaming Provisions Benefit Tourists and Traders. Melbourne Journal of International Law 17: 404-42.

Kreps, Daniel. 2016. Taylor Swift, McCartney Sign Petition for Digital Copyright Reform. Rolling Stone, June 20. Available online: http:/ / www.rollingstone.com/music/news/taylor-swift-mccartney-sign-petition-fordigital-copyright-reform-20160620 (accessed on 1 July 2017).

Lee, Timothy. 2013. Leaked Treaty is a Hollywood Wish List. Could it Derail Obama's Trade Agenda? The Washington Post, November 13. Available online: http:/ / www.washingtonpost.com/blogs/the-switch/wp/ 2013/11/13/leaked-treaty-is-a-hollywood-wish-list-could-it-derail-obamas-trade-agenda/ (accessed on 1 July 2017).

Lessig, Lawrence. 2015. Expert Opinion in the Kim Dotcom Extradition Case. Techfirm, September 16. Available online: http:/ / www.techfirm.com/professor-lessig-opinion-in-ki/ (accessed on 1 July 2017).

C.L. Lim, Deborah Elms, and Patrick Low, eds. 2012. The Trans-Pacific Partnership: A Quest for a Twenty-First Century Trade Agreement. Cambridge: Cambridge University Press.

Litman, Jessica. 2001. Digital Copyright. New York: Prometheus Books.

Love, James. 2013. Knowledge Ecology International analysis of TPP IPR Text. November 13. Available online: http:/ / keionline.org/node/1825 (accessed on 1 July 2017).

Ludlam, Senator Scott. 2013. Greens act to expose threats to Australians after damning leak of secret trade deal document. Press Release. November 14. Available online: http:/ / scott-ludlam.greensmps.org.au/content/ media-releases / greens-act-expose-threats-australians-after-damning-leak-secret-trade-deal-do (accessed on 1 July 2017).

Malcolm, Jeremy. 2015. How the TPP Perpetuates the Mistakes of the DMCA. Electronic Frontier Foundation, December 17. Available online: https:/ /www.eff.org/deeplinks/2015/12/how-tpp-perpetuates-mistakesdmca (accessed on 1 July 2017).

Malcolm, Jeremy. 2016. RCEP: The Other Closed-Door Agreement to Compromise Users' Rights. Electronic Frontier Foundation, April 20. Available online: https:/ / www.eff.org/deeplinks/2016/04/RCEP-otherclosed-door-agreement-compromise-users-rights (accessed on 1 July 2017).

Malcolm, Jeremy. 2017. NAFTA Renegotiation will Resurrect Failed TPP Proposals. Electronic Frontier Foundation, March 31. Available online: https: / www.eff.org/deeplinks/2017/03/nafta-renegotiation-will-resurrectfailed-tpp-proposals (accessed on 1 July 2017).

Mapp, Wayne. 2011. Copyright (Infringing File Sharing) Amendment Bill. Wellington: New Zealand Parliament, April 12, Available online: https:/ / www.parliament.nz/en/pb/hansard-debates/rhr/document/49HansD_ 20110413_00001942/copyright-infringing-file-sharing-amendment-bill-second (accessed on 1 July 2017).

Martin, Peter. 2013. Australia backs the US at every turn against its Own Consumers. The Sydney Morning Herald, November 13. Available online: http:/ / www.smh.com.au/federal-politics/political-news/australia-backsthe-us-at-every-turn-against-its-own-consumers-20131113--2xh0p.html (accessed on 1 July 2017). 
Martin, Peter. 2017. Fair Use: Wikipedia Targets Australians in Bid to Change the Law. The Sydney Morning Herald, May 21. Available online: http:/ / www.smh.com.au/federal-politics/political-news / fair-use-wikipediatargets-australians-in-bid-to-change-the-law-20170521-gw9kzq.html (accessed on 1 July 2017).

Masnick, Mike. 2016a. DMCA's Notice and Takedown Procedure is a Total Mess, and It's Mainly Because of Bogus Automated Takedowns. Techdirt, March 30. Available online: https:/ / www.techdirt.com/articles/20160330/01583234053/dmcas-notice-takedown-procedure-istotal-mess-mainly-because-bogus-automated-takedowns.shtml (accessed on 1 July 2017).

Masnick, Mike. 2016b. EFF Lawsuit Challenges DMCA's Digital Locks Provision as First Amendment Violation. Techdirt, July 21. Available online: https:/ / www.techdirt.com/articles/20160721/10223135031/eff-lawsuitchallenges-dmcas-digital-locks-provision-as-first-amendment-violation.shtml (accessed on 1 July 2017).

Mason, Max. 2016. Village Roadshow, Hollywood Studios Move to Block Piracy Website SolarMovie. Australian Financial Review, February 18. Available online: http:/ /www.afr.com/business/media-and-marketing/ village-roadshow-hollywood-to-block-solarmovie-20160217-gmwoay (accessed on 1 July 2017).

McSherry, Corynne, and Maira Sutton. 2013. Another Reason to Hate TPP: It Gives Big Content New Tools to Undermine Sane Digital Rights Policies. Electronic Frontier Foundation, October 24. Available online: https: / / www.eff.org/deeplinks / 2013/10/another-reason-hate-tpp-it-gives-big-content-new-toolsundermine-sane-digital (accessed on 1 July 2017).

Ministry of Business, Innovation, and Employment, New Zealand Government. 2017. Review of the Copyright Act. Available online: http:/ / www.mbie.govt.nz/info-services/business/intellectual-property/copyright/ review-copyright-act-1994 (accessed on 1 July 2017).

Mishra, Nehra. 2017. The Role of the Trans-Pacific Partnership Agreement in the Internet Ecosystem. Journal of International Economic Law 20: 31-60. [CrossRef]

David Moon, Patrick Ruffini, and David Segal, eds. 2013. Hacking Politics: How Geeks, Progressives, The Tea Party, Gamers, Anarchists and Suits Teamed up to Defeat SOPA and Save the Internet. London and New York: OR Books.

Nguyen, Minh, and Deborah Elms. 2016. TPP Rules for Digital Trade in Asia, Asian Trade Centre. November 29. Available online: https:/ / www.adb.org/news/events/trade-digital-economy (accessed on 1 July 2017).

NordVPN. 2016. TPP Agreement: Implications on Internet Freedom and Reasons to Stop It from Passing. Press Release. June 17. Available online: https:/ / nordvpn436.newswire.com/news/tpp-agreement-implicationson-internet-freedom-and-reasons-to-stop-it-12059906 (accessed on 1 July 2017).

Obama, President Barack. 2015. Statement on the Trans-Pacific Partnership, White House. October 5. Available online: https: / / obamawhitehouse.archives.gov / the-press-office/2015/10/05/statement-president-transpacific-partnership (accessed on 1 July 2017).

Okediji, Ruth. 2003-2004. Back to Bilateralism: Pendulum Swings in Intellectual Property Protection. University of Ottawa Law and Technology Journal 1: 125-47.

Opsahl, Kurt, and Carolina Rossini. 2012. TPP Creates Legal Incentives for ISPs to Police the Internet, What is at Risk? Your Rights. Electronic Frontier Foundation, August 24. Available online: https: / /www.eff.org/ deeplinks / 2012/08/tpp-creates-liabilities-isps-and-put-your-rights-risk (accessed on 1 July 2017).

Pallante, Maria. 2013. The Next Great Copyright Act. Columbia Journal of Law and the Arts 36: 315-44.

Palmer, Darren, and Ian Warren. 2013. Global Policing and the Case of Kim Dotcom. Crime Justice Journal. Available online: https:/ / www.crimejusticejournal.com/article/view/105 (accessed on 1 July 2017).

Pappalardo, Kylie. 2014. Duty and Control in Intermediary Copyright Liability: An Australian Perspective. IP Theory 4: 9-27.

Parker, Lisa. 2014. Movie Studio Targets Consumers for Illegal Downloads, NBC Chicago. May 2. Available online: http://www.nbcchicago.com/investigations/Movie-Studio-Targets-Consumers-ForIllegal-Downloads-257608961.html (accessed on 1 July 2017).

Pearce, Rohan. 2017. Foxtel Wants Australia's Biggest ISP's to Block 17 Pirate Sites. Computer World Australia. June 2. Available online: https:/ / www.computerworld.com.au/article/620145/foxtel-wants-australia-biggestisps-block-17-sites/ (accessed on 1 July 2017).

Perzanowski, Aaron, and Jason Schultz. 2016. The End of Ownership: Personal Property in the Digital Economy. Cambridge and London: The MIT Press.

Productivity Commission. 2016. Intellectual Property Arrangements_Draft Report; Melbourne: Productivity Commission. Available online: http://www.pc.gov.au/inquiries/current/intellectual-property/draft/ intellectual-property-draft.pdf (accessed on 1 July 2017). 
Productivity Commission. 2016. Intellectual Property Arrangements; Report No. 78; Melbourne: Productivity Commission. Available online: http:/ / www.pc.gov.au/inquiries/completed/intellectual-property/report (accessed on 1 July 2017).

Pullar-Strecker, Tim. 2012. Four in 10 Kiwis Still Flout Piracy Laws. The Dominion Post, July 23. Available online: http:/ / www.stuff.co.nz/technology / digital-living/7318453/Four-in-10-Kiwis-still-flout-piracylaws (accessed on 1 July 2017).

Pullar-Strecker, Tom. 2015. US Movie Studio Threatens Kiwi Film Pirates. Business Day, April 9. Available online: http:/ / www.stuff.co.nz/business / 67657478/us-movie-studio-threatens-kiwi-film-pirates (accessed on 1 July 2017).

Reuters and AAP. 2015. Kim Dotcom's Extradition to US Cleared by New Zealand Judge. The Guardian, December 23. Available online: https:/ / www.theguardian.com/technology/2015/dec/23/kim-dotcoms-extraditionto-us-cleared-by-new-zealand-judge?CMP=twt_gu (accessed on 1 July 2017).

Rimmer, Matthew. 2006. Robbery under Arms: Copyright Law and the Australia-United States Free Trade Agreement. Available online: http:/ / firstmonday.org/ojs/index.php/fm/article/view/1316 (accessed on 1 July 2017).

Rimmer, Matthew. 2007. Digital Copyright and the Consumer Revolution: Hands off My iPod. Cheltenham: Edward Elgar.

Rimmer, Matthew. 2009. Wikipedia, Collective Authorship, and the Politics of Knowledge. In Intellectual Property Policy Reform: Fostering Innovation and Development. Edited by Christopher Arup and William Van Caenegem. Cheltenham: Edward Elgar, pp. 172-98.

Rimmer, Matthew. 2013. Clash of the Titans: Apple, Adobe, and Microsoft under Fire at the IT Pricing Inquiry. The Conversation. March 22. Available online: https:/ theconversation.edu.au/clash-of-the-titans-appleadobe-and-microsoft-under-fire-at-it-pricing-inquiry-12878 (accessed on 1 July 2017).

Rimmer, Matthew. 2014. Trick or Treaty? The Australian Debate over the Anti-Counterfeiting Trade Agreement (ACTA). In The ACTA and the Plurilateral Enforcement Agenda: Genesis and Aftermath. Edited by Pedro Roffe and Xavier Seuber. Geneva: International Centre for Trade and Sustainable Development, Cambridge: Cambridge University Press, pp. 169-201.

Rimmer, Matthew. 2015. The Trans-Pacific Partnership Deal Protects Old Companies at the Expense of the New. $A B C$, The Drum. October 6. Available online: http://www.abc.net.au/news/2015--10--06/rimmer-tppfavours-old-ip-industries / 6830884 (accessed on 1 July 2017).

Rimmer, Matthew. 2017a. The Dancing Baby: Copyright Law, YouTube, and Music Videos. In Research Handbook on Intellectual Property in Media and Entertainment. Edited by Megan Richardson and Sam Ricketson. Cheltenham: Edward Elgar, pp. 150-94.

Rimmer, Matthew. 2017b. The Foxfire of Fair Use: The Google Books Litigation and the Future of Copyright Laws. Oxford Research Encyclopedia of Communication. Available online: http:/ / communication.oxfordre.com/view / 10.1093/acrefore/9780190228613.001.0001/acrefore-9780190228613-e-274 (accessed on 1 July 2017).

Rintel, Sean. 2013. No Fair, No Share: Australia Sells Out ... Again. Electronic Frontiers Australia, November 14. Available online: https:/ / www.efa.org.au/2013/11/14/tpp-no-fair-no-share/ (accessed on 1 July 2017).

Pedro Roffe, and Xavier Seuber, eds. 2014. The ACTA and the Plurilateral Enforcement Agenda: Genesis and Aftermath. Geneva: International Centre for Trade and Sustainable Development, Cambridge: Cambridge University Press.

Sell, Susan. 2011. TRIPS Was Never Enough: Vertical Forum Shifting, FTAS, ACTA, and TPP. Journal of Intellectual Property Law 18: 448-78.

Seno, Shigeru. 2017. Australia Wants TPP Despite US Exit: Trade Minister. Nikkei Asian Review. April 20. Available online: http:/ / asia.nikkei.com/Politics-Economy /International-Relations / Australia-wants-TPP-despiteUS-exit-trade-minister (accessed on 1 July 2017).

Sheppard, Felicity. 2016. The Dallas Buyers Club Case Has Been Abandoned But Illegal Downloaders May Still Face Trouble. ABC. February 12. Available online: http://www.abc.net.au/news/2016--02--12/dallasbuyers-club-case-abandoned-illegal-dowloads-pirate/7162180 (accessed on 1 July 2017).

Sims, Alexandra. 2016. The Case for Fair Use in New Zealand. International Journal of Law and Information Technology 24: 176-202. [CrossRef]

Sinclair, Scott, and Stuart Trew, eds. 2016. The Trans-Pacific Partnership and Canada: A Citizen's Guide. Toronto: James Lorimer \& Company Ltd. 
Snider, Mike. 2016. Taylor Swift Sets Sights on YouTube as 180 Music Artists Lobby for Copyright Reform. The Sydney Morning Herald, June 22. Available online: http:/ / www.smh.com.au/entertainment/music/taylorswift-sets-sights-on-youtube-as-180-music-artists-lobby-for-copyright-reform-20160622-gppisx.html (accessed on 1 July 2017).

Spangler, Todd. 2017. Entertainment Giants Forge New Alliance to Fight Piracy, Sue Offenders. Variety, June 13. Available online: http:/ / variety.com/2017/digital/news/entertainment-studios-piracy-lawsuits1202463987 / (accessed on 1 July 2017).

Standing Committee on International Trade. 2017. The Trans-Pacific Partnership Agreement: Benefits and Challenges for Canadians. House of Commons, 42nd Parliament, 1st Session, Canadian Parliament. Available online: http:/ / www.parl.gc.ca/HousePublications /Publication.aspx?DocId=8828808\&Language= E\&Mode $=1 \&$ Parl=42\&Ses=1 (accessed on 1 July 2017).

Stiglitz, Joseph. 2012. The Price of Inequality. London and New York: Allen Lane.

Stiglitz, Joseph. 2013. Open Letter to TPP Negotiators, Knowledge Ecology International. December 6. Available online: http:/ / keionline.org/node/1845 (accessed on 1 July 2017).

Stiglitz, Joseph. 2016. In 2016, Let's Hope for Better Trade Agreements-And the Death of TPP. The Guardian, January 10. Available online: https:/ / www.theguardian.com/business/2016/jan/10/in-2016-better-tradeagreements-trans-pacific-partnership (accessed on 1 July 2017).

Stiglitz, Joseph. 2016. Tricks of the Trade: Six Big Problems with the Trans-Pacific Partnership, Roosevelt Institute. March 28. Available online: http:/ / rooseveltinstitute.org/tricks-trade-deal-six-big-problems-trans-pacificpartnership/ (accessed on 1 July 2017).

Stiglitz, Joseph, Nell Abernathy, Adam Hersh, Susan Holmberg, and Mike Konczal. 2016. Rewriting the Rules of the American Economy: An Agenda for Growth and Shared Prosperity. New York and London: WW Norton \& Company.

Stiglitz, Joseph, and Adam Hersh. 2015. The Trans-Pacific Free Trade Charade. Project Syndicate, October 2. Available online: https:/ / www.project-syndicate.org/commentary/trans-pacific-partnership-charade-byjoseph-e--stiglitz-and-adam-s--hersh-2015-10?barrier=accessreg (accessed on 1 July 2017).

Stoltz, Mitch. 2017. Copyright Office Proposes Modest Fixes to DMCA 1201, Leaves Fundamental Flaws Untouched. Electronic Frontier Foundation, June 28. Available online: https:/ / www.eff.org/deeplinks / 2017/06/copyright-office-proposes-modest-fixes-dmca-1201-leaves-fundamental-flaws (accessed on 1 July 2017).

Sunstein, Cass. 2017. \#republic: Divided Democracy in the Age of Social Media. Princeton: Princeton University Press. Sutton, Maira. 2015. The TPP State of Play: How We Defeat the Largest Trade Deal in History. Electronic Frontier Foundation, December 1. Available online: https:/ / www.eff.org/deeplinks/2015/12/tpp-current-stateplay-how-we-defeat-largest-trade-deal (accessed on 1 July 2017).

Swan, David. 2015. iiNet Loses Dallas Buyers Club Landmark Piracy Case. Business Spectator, April 7. Available online: https:/ / www.businessspectator.com.au/news/2015/4/7/technology/iinet-loses-dallas-buyersclub-landmark-piracy-case (accessed on 1 July 2017).

Swan, David. 2017. Redbubble Seeks a Safe Harbour. The Australian, March 28. Available online: http:/ / www.theaustralian.com.au/business/technology/redbubble-seeks-a-safe-harbour/newsstory/306d40281f23ddca4df6b3561f487f29 (accessed on 1 July 2017).

Sydell, Laura. 2015. DIY Tractor Repair Runs Afoul of Copyright Law. NPR, August 17. Available online: http:/ / www.npr.org/sections/alltechconsidered/2015/08/17/432601480/diy-tractor-repair-runsafoul-of-copyright-law (accessed on 1 July 2017).

Technology Companies. 2014. Letter to Senator Ron Wyden. March 20. Available online: https:/ / www.eff.org/ files/2014/03/20/tech-companies-wyden-letter-20140320.pdf (accessed on 1 July 2017).

Tham, Irene. 2015. Pay \$5K For Illegal Download of Movie. The Straits Times, August 8. Available online: http:/ / www.straitstimes.com/singapore/courts-crime/pay-5k-for-illegal-download-of-movie (accessed on 1 July 2017).

The Joint Standing Committee on Treaties. 2016. Report 165: Trans-Pacific Partnership Agreement; Canberra: Australian Parliament. Available online: http:/ /www.aph.gov.au/Parliamentary_Business/Committees / Joint/Treaties/TransPacificPartnership/Report_165 (accessed on 1 July 2017). 
Ting-Edwards, James, Melanie Johnson, Judge David Harvey, Debbie Monahan, Kate McHaffie, and Jo Shaw. 2016. TPPA: Intellectual Property and Information Technology. Available online: https:/ / tpplegal.files.wordpress. com/2015/12/tpp-ip-it.pdf (accessed on 1 July 2017).

Tushnet, Rebecca. 2016. Copyright Office 512 Roundtable: Future of 512. Rebecca Tushnet's 43(B)log. May 3. Available online: http:/ / tushnet.blogspot.com.au/2016/05/copyright-office-512-roundtable-future.html (accessed on 1 July 2017).

United States Copyright Office. 2017a. Section 512 Study; Washington: United States Copyright Office. Available online: https: / www.copyright.gov/policy/section512/ (accessed on 1 July 2017).

United States Copyright Office. 2017b. Section 1201 Study; Washington: United States Copyright Office. Available online: https: / / www.copyright.gov/policy/1201/ (accessed on 1 July 2017).

United States Copyright Office. 2017c. Section 1201 of Title 17; Washington: United States Copyright Office. Available online: https://www.copyright.gov/policy/1201/section-1201-full-report.pdf (accessed on 1 July 2017).

The United States Trade Representative. 2015a. Chapter Summary-Chapter 18 of the Trans-Pacific Partnership 2015: Intellectual Property. Available online: https://medium.com/the-trans-pacific-partnership/intellectualproperty-3479efdc7adf\#.iyktmxkbw (accessed on 1 July 2017).

The United States Trade Representative. 2015b. Chapter 18 of the Trans-Pacific Partnership 2015: Intellectual Property. Available online: https:/ / ustr.gov/sites/default/files/TPP-Final-Text-Intellectual-Property.pdf (accessed on 1 July 2017).

The United States Trade Representative. 2015c. Overview. Intellectual Property Chapter of the Trans-Pacific Partnership. Available online: https:/ / medium.com/the-trans-pacific-partnership/intellectual-property3479efdc7adf\#.lcowp4odl (accessed on 1 July 2017).

The United States Trade Representative. 2016. Special 301 Report. Available online: https://ustr.gov/sites/ default/files/USTR-2016-Special-301-Report.pdf (accessed on 1 July 2017).

Urban, Jennifer, Joe Karaganis, and Brianna Schofield. 2016. Notice and Takedown in Everyday Practice. Available online: http: / / ssrn.com/abstract=2755628 (accessed on 1 July 2017).

Urban, Jennifer, Joe Karaganis, and Brianna Schofield. 2017. Response to Notice and Takedown in Everyday Practice: A Review. Available online: http:/ / takedownproject.org/770-2 (accessed on 1 July 2017).

Van Harten, Gus. 2017. Is it Time to Redesign or Terminate Investor-State Arbitration. Centre for International Governance Innovation, April 11. Available online: https:/ /www.cigionline.org/articles/it-time-redesignor-terminate-investor-state-arbitration (accessed on 1 July 2017).

Voon, Tania. 2013. Trade Liberalisation and International Co-Operation: A Legal Analysis of the Trans-Pacific Partnership Agreement. Cheltenham and Northampton: Edward Elgar.

Wagman, Ira, and Peter Urquhart. 2014. This Content is not available in your Region: Geoblocking Culture in Canada. In Dynamic Fair Dealing: Creating Canadian Culture Online. Edited by Rosemary Coombe, Darren Wershler and Martin Zeilinger. Toronto: University of Toronto Press, pp. 124-32.

Walsh, Kit. 2016. Section 1201 of the DMCA Cannot Pass Constitutional Security. Electronic Frontier Foundation. July 21. Available online: https://www.eff.org/deeplinks/2016/07/section-1201-dmca-cannot-passconstitutional-scrutiny (accessed on 1 July 2017).

Weatherall, Kimberlee. 2016a. Intellectual Property in the TPP: Not the New TRIPS. Melbourne Journal of International Law 17: 1-29. Available online: http://law.unimelb.edu.au/_data/assets/pdf_file/0010/ 2214478/01-Weatherall.pdf (accessed on 1 July 2017).

Weatherall, Kimberlee. 2016b. Safeguards for Defendant Rights and Interests in International Intellectual Property Enforcement Treaties. American University International Law Review 32: 211-77.

Whitbourn, Michaela. 2015. Dallas Buyers Club Judgment: The Trans-Pacific Partnership Could be Worse News for Online Pirates. The Sydney Morning Herald, April 12. Available online: http:/ / www.smh.com.au/digital-life/digital-life-news/dallas-buyers-club-judgment-transpacificpartnership-could-be-worse-news-for-online-pirates-20150411--1mh6td.html?stb=twt (accessed on 1 July 2017).

The White House. 2017. Presidential Memorandum Regarding Withdrawal of the United States from the Trans-Pacific Partnership Negotiations and Agreement. Press Release. January 23. Available online: https: / /www.whitehouse.gov/the-press-office/2017/01/23/presidential-memorandum-regardingwithdrawal-united-states-trans-pacific (accessed on 1 July 2017). 
Wiens, Kyle. 2015a. We Can't Let John Deere Destroy the Very Idea of Ownership. Wired Magazine, April 21. Available online: http:/ / www.wired.com/2015/04/dmca-ownership-john-deere/ (accessed on 1 July 2017).

Wiens, Kyle. 2015b. John Deere Responds to Copyright Mess It Made. IFixit News, May 13. Available online: http:/ /ifixit.org/blog/7192/john-deere-mess / (accessed on 1 July 2017).

The Wikimedia Foundation. 2016. What's the TPP? The Problematic Partnership. Wikimedia Policy, February 3. Available online: https://medium.com/wikimedia-policy/what-s-tpp-the-problematic-partnership6751951872cc\#.ipq326309 (accessed on 1 July 2017).

Yu, Peter. 2017a. The Investment-Related Aspects of Intellectual Property Rights. American University Law Review 66: 829-910.

Yu, Peter. 2017b. The RCEP and Intellectual Property Norm-Setting in the Asia-Pacific, Intellectual Property Rights and Mega-Regional Trade Agreements. Available online: https:/ / papers.ssrn.com/sol3/papers.cfm? abstract_id=2810579 (accessed on 1 July 2017).

(C) 2017 by the author. Licensee MDPI, Basel, Switzerland. This article is an open access article distributed under the terms and conditions of the Creative Commons Attribution (CC BY) license (http:/ / creativecommons.org/licenses/by/4.0/). 